\title{
Global Sourcing under Imperfect Capital MARKETS
}

\author{
Juan Carluccio* and Thibault Fally**
}

* Banque de France and Paris School of Economics, 33 Rue Croix des Petits Champs 75001, Paris, France. juan.carluccio@pse.ens.fr, +33677357305. ** Department of Economics, University of Colorado at Boulder, 256 UCB Boulder, Colorado 80309-0256, USA. fally@colorado.edu, +13034925562. 
We are grateful to Thierry Verdier for his invaluable guidance and support. We thank Philippe Aghion, Pol Antras, Arnaud Costinot, Quy-Toan Do, Marc Gurgand, Elhanan Helpman, Giordano Mion, Romain Rancière, Dani Rodrik and seminar participants at the Paris School of Economics, Ecole Polytechnique, Harvard University, LACEA-LAMES, CEPII, University of Texas-Austin, UCSD, University of Toronto, University of ColoradoBoulder, UPF-CREI, Universidad de San Andres, University of Sydney, Melbourne University and the Bank of France for their helpful comments. We also thank Karolina Ekholm, Richard Kneller, Andrei Levchenko, Pierre Mohnen and seminar participants for their comments on earlier versions. 


\begin{abstract}
We develop a simple model to study the interactions between a supplier's financial constraints and contract incompleteness in a vertical relationship. Applied to the analysis of multinational firms' sourcing strategies the model predicts that (1) complex and specific inputs are more likely to be sourced from financially developed countries and (2) multinationals are more likely to integrate suppliers located in countries with poor financial institutions, especially when trade involves complex goods. These predictions are examined and validated using firm-level trade data on multinational firms with operations in France.
\end{abstract}

Keywords: financial constraints, contractual frictions, sourcing, FDI.

JEL Classification: L23, O16, F10. 


\section{Introduction}

The process of globalization is characterized by the growing fragmentation of production and the organization of firms' activities on a global scale. A substantial amount of empirical evidence has documented the importance of trade in intermediate goods in total world trade and the extent of vertical specialization (Yeats, 2001; Feenstra, 1998; Campa and Goldberg, 1997; Hummels, Ishii and Yi, 2001). Moreover, multinational firms account for a large proportion of world trade, with affiliated or independent partners. ${ }^{1}$

Firms seeking to exploit cross-country differences in production costs interact with suppliers operating in environments with varying levels of institutional quality. One important institutional dimension is access to finance. Previous research has shown that it strongly impacts on investment, firm performance and exports (King and Levine, 1993; Rajan and Zingales, 1998; Manova, 2008). However, local financial markets are not the only source of finance for suppliers and there is also evidence of capital flows from multinational firms to affiliates as potential channels to overcome imperfections in local capital markets (Desai et al, 2004a).

The purpose of this paper is to analyze how multinational firms' sourcing strategies are affected by suppliers' financial constraints and the financial development of the countries in which they operate. We show that financial constraints interact with the extent of contract incompleteness in vertical trade. The model predicts that the profitability of offshoring production increases, ceteris paribus, with the level of financial development of the destination country. In particular, this effect is stronger in industries with higher degrees of technological complexity and specificity, with greater dependence on non-contractible investments and tasks. We show that vertical integration of the supplier alleviates financial constraints, and thus intra-firm trade arises in complex industries 
especially when local capital markets are imperfect. The model's main empirical predictions are then tested and validated against firm-level trade data on the operations of multinational firms located in France.

Recent theoretical and empirical research has established that contractual frictions are strong determinants of trade patterns and the cross-border organization of firms (see Antras and Rossi-Hansberg, 2009). Wide variations are observed in the extent of contract incompleteness and its impact, depending on the type of product that is traded. In particular, the level of product complexity appears to be one of the main determinants of contract incompleteness. ${ }^{2}$ In our model, complex products refer to goods involving a higher proportion of complex tasks and components that cannot be fully described in a contract. We focus on one supplier producing an input for one final good producer - the multinational firm. The greater the product complexity, the greater the hold-up problem ex post between both parties. A multinational sourcing complex inputs only secures a limited fraction of ex-post gains while the upstream party captures a positive rent. Therefore, the multinational refrains from financing the supplier's initial costs and may even ask ex ante for a compensating transfer (e.g. licensing fee). Because of this, the supplier's need for initial liquidity is inherently related to the level of input complexity. Supplying complex products calls for adequate financial capacity whereas the production of basic inputs can rely on co-financing from the multinational.

As is well known from the property rights theory of the firm (Grossman and Hart, 1986; Hart and Moore, 1990), one way of solving the problems of incomplete contracts is with a suitable allocation of ownership. The theory posits that efficiency requires residual property rights to be assigned to the party whose non-contractible investments have the greatest marginal effect on the joint value. In the absence of credit constraints, the supplier should remain independent assuming that its specific investments are essential to produce the intermediate input. Capital market frictions, however, limit the supplier's capacity to finance the initial cost of outsourcing with the multinational firm. In this 
case, we show that allocating residual property rights to the multinational firm reduces the need for supplier's financial participation. Therefore, vertical integration can arise as an equilibrium organizational form, even when it is suboptimal in terms of productive efficiency.

An important determinant of financial constraints is the level of financial development of the country in which the supplier is located. In the model, the upstream producer operates in an environment plagued with financial frictions that impose a bound on its access to liquidity. In addition to their initial contribution, we assume that suppliers can raise debt from local banks, depending on the level of financial development. A higher level of financial development is characterized by a larger proportion of pledgeable future income.

A first prediction of the model is that imperfect capital markets have a differential effect on complex input offshoring decisions. We look at differential effects across industries and show that financial development generates a comparative advantage in the supply of complex inputs. The grounds for this can be seen from Figure 1. The graph shows that the share of exports in complex industries (broadly speaking: machinery, equipment and chemicals) is highly correlated with the level of financial development. ${ }^{3}$

[Figure 1 about here]

The model also predicts that the share of intra-firm imports by multinational firms should be higher in countries with lower levels of financial development. Moreover, this effect should be more pronounced for complex inputs. Multinational firms should be more likely to integrate their suppliers as a means to alleviate their financial constraints and reduce exposure to opportunism in countries where financial development is low. Complex industries are those where the costs of outsourcing are higher for the reasons described above, and thus where financial constraints are more likely to bind.

The model's predictions are tested in the empirical section of the paper. We use 
data on imports by multinational firms located in France (manufacturing groups with at least one affiliate abroad), detailed by firm, product and country of origin. An important feature of these data is that they provide the proportion of intra-firm trade for each observation. Our econometric analysis shows that multinational firms are less likely to trade complex inputs with suppliers located in countries with lower levels of financial development. Furthermore, when financial development is low, imports of complex inputs are more likely to occur within the boundaries of the firm, from an affiliate. These findings are robust to different measures of financial development and complexity: R\&D intensity measured in France and Rauch (1999) classification of differentiated versus homogeneous goods. ${ }^{4}$ Moreover, our results persist after the inclusion of firm fixed-effects and are not driven by reverse causality. Quantitatively, financial development has a statistically and economically significant impact on imports, depending on the complexity of the traded good. We estimate that a one standard deviation change in our index of financial development yields a $9 \%$ increase in the probability of imports of complex goods compared to basic goods (with a difference of one standard deviation in the index of complexity). This effect is larger than or comparable to the effect of contract enforcement on the composition of imports.

Our paper contributes to the literature on institutions and trade (Acemoglu et al., 2007; Levchenko, 2007; Costinot, 2009; Nunn, 2007) and more specifically on financial development and trade (Beck, 2003; Manova, 2006 and 2008; Svaleryd and Vlachos, 2005). The main idea behind most studies in this literature is that potential exporters with high initial costs need external finance, unless they have a sufficient amount of cash in hand (Beck 2002; Chaney, 2005; Manova, 2006; Manova et al 2009; Becker and Greenberg, 2007). ${ }^{5}$ This view, however, overlooks the fact that a large proportion of trade involves multinational firms that can directly finance their suppliers' initial costs, especially when the supplier is an affiliate. By contrast, in our model, the need for external finance is the result of a tension between suppliers and multinational firms when 
production relies on complex tasks and components that cannot be described in contracts. In recent work, Basco (2008) studies the role of financial development in the product cycle in international trade and suggests that financial development interacts with the intensity in headquarter services to determine the location of production. ${ }^{6}$ Our empirical results support, however, the notion put forward by our theory that financial development creates a comparative advantage in complex and specific goods. In our data, the impact of financial development is not driven by interactions with the traditional index of external financial dependence (Rajan and Zingales, 1998), alternative measures of fixed costs, or different indices of headquarter intensity. Moreover, our estimates suggest a stronger role of financial development compared to the rule of law and intellectual property rights.

Our paper also contributes to the literature on the determinants of intra-firm trade. It is the first to examine (theoretically and empirically) the role of financial constraints and financial development on the share of intra-firm trade. Previous theoretical studies have analyzed the role of intellectual property rights (Ethier and Markusen, 1996), capital endowments (Antras, 2003) and contract enforcement (Antras and Helpman, 2008), ${ }^{7}$ but our empirical analysis suggests that financial development plays a comparable if not greater role. Moreover, our model combines predictions on comparative advantage and intra-firm trade in a simple way. Integration of the supplier eases financial constraints by taking formal control of the production of complex products when the supplier is located in a country with poor financial institutions. A different mechanism is at work in the recent model developed by Antras et al. (2009) to analyze the role of weak investor protection in the horizontal FDI versus technology licensing decision (agents do not trade), where direct financial participation by the multinational is considered by the local bank to be a guarantee of monitoring (in line with Holmstrom and Tirole, 1997).

More broadly, our theory is related to the literature on the interactions between financial constraints and control in corporate finance, first developed by Aghion and Bolton (1992) and later applied in Aghion and Tirole (1994) and Legros and Newman (2003), 
among others. Our model focuses on vertical relationships, but the mechanism presents similarities with the trade-off between debt and control, where the investor prefers to take control of the firm when the entrepreneur cannot raise enough debt. On the empirical side, recent works by Machiavello (forthcoming) and Acemoglu, Johnson and Mitton (2009) have studied how contracting costs and financial development interact in the determination of firms' boundaries in a closed economy, using cross-country data. Applying these questions to international trade turns up some interesting and proper identification strategies absent from closed economy studies. An analysis of the choice of import origin permits to identify the impact of the suppliers' environment independently from the location of the downstream firm. In addition, it permits to observe variations in the size of imports and sourcing modes (integration or outsourcing) by country of origin for the same downstream firm. Our empirical study thus draws on direct information on sourcing mode by firm, whereas the abovementioned studies have to rely on indirect measures of vertical integration such as those calculated on the basis of input-output matrices and the ratio of value added to total sales.

The paper is organized as follows. Section 2 develops a model that formalizes the interactions between a multinational firm and a supplier in an incomplete contract setting, where the latter has limited access to finance. Section 3 presents the empirical analysis based on firm-level trade data on French multinational firms. Section 4 concludes.

\section{Theory}

\subsection{A simple model}

Our model is based on a simplified version of the Antras and Helpman (2008) model of global sourcing, incorporating capital market frictions on the supplier's side. 


\section{Production: basic and complex tasks}

We consider two agents in a vertical relationship: a downstream firm (referred to as the "multinational firm", labeled M) and the manager of a local upstream firm (the "supplier", labeled S). The supplier produces an intermediate good that is traded to the multinational firm, which then produces and sells the final good.

Total revenues from final good sales equal $Y=A^{1-\rho} Q^{\rho}$ where $Q$ denotes the volume of production and $A$ is a constant that reflects the perceived demand schedule. This expression can be derived from the Dixit-Stiglitz (1977) model of monopolistic competition with constant elasticity of substitution (CES) between final goods. We denote the elasticity of substitution by $\sigma=\frac{1}{1-\rho}>1$, with $0<\rho<1$ measuring the degree of product differentiation.

The multinational firm needs one unit of an input to produce one unit of a final good. In turn, the supplier needs to undertake a continuum of tasks to produce the intermediate good. We normalize to one the measure of the set of tasks. Each task can be taken to be the production of a single component of the intermediate good.

There are two types of tasks: complex and basic. Contrary to basic tasks, complex tasks are specific and cannot be fully described in a contract. They correspond to attributes and components of the intermediate good that are not verifiable by a third party. We denote by $\theta$ the proportion of complex tasks required for the production of the input. $\theta$ is thus a parameter that characterizes the input's industry.

Each task $i$ demands an effort from the supplier, denoted $x_{i}$. The unit cost of effort put into each task is constant and denoted by $c$. We assume that the production technology is represented by a CES function where tasks are imperfect substitutes. To be more precise, the volume of production equals:

$$
Q=\left[\int_{I} x_{i}^{\rho^{\prime}} \mathrm{d} i\right]^{\frac{1}{\rho^{\prime}}}
$$


where $I$ refers to the set of tasks and $\frac{1}{1-\rho^{\prime}}>1$ to the elasticity of substitution. Symmetrically, the level of effort is the same for all complex tasks and all basic tasks respectively. We denote by $e$ the level of effort in complex tasks and by $q$ the level of effort in basic tasks.

We assume, for the sake of argument, that the elasticity of substitution between tasks is the same as it is between final goods $\left(\rho=\rho^{\prime}\right)$, producing a simple linear form for the value of total sales. This assumption allows us to obtain a simple linear expression of total revenues as a function of the degree of complexity: ${ }^{8}$

$$
Y=A^{1-\rho}\left[\theta e^{\rho}+(1-\theta) q^{\rho}\right]
$$

Total costs sum up to:

$$
C=\theta c e+(1-\theta) c q
$$

Notice that we do not rely on the assumption of fixed costs, but they could simply be added to this framework.

\section{Organizational form and ex post bargaining}

The inability to contract on the level of investment $e$ in complex tasks results in ex-post bilateral bargaining over the surplus. Efforts in all tasks are implemented by the supplier before the bargaining stage. However, in the event that no agreement is reached in the bargaining stage, efforts in complex tasks can be wiped out by the supplier, while efforts in basic tasks must follow the contract's specifications.

We model the bargaining game using the Nash bargaining solution with symmetric bargaining shares. When negotiations are through, each party obtains half of the quasirents generated by the partnership plus its outside option, represented by the value of the better alternative available in the event of no agreement (threat point).

In keeping with Grossman and Hart (1986), outside options are assumed to be contin- 
gent on the prevailing organizational structure, determined by the party that is assigned the property rights over the input. We consider two forms of organizational structure. Under a non-integration, or "outsourcing" arrangement, the supplier retains residual property rights. Nevertheless, we suppose that efforts in complex tasks are specific and sunk, which implies that the supplier's outside option is zero, irrespective of organizational form. Analytically, outside outsourcing options are given by the first line of the following table: ${ }^{9}$

\begin{tabular}{l|l|l} 
Outside options & Supplier S & Multinational M \\
\hline Outsourcing & 0 & $A^{1-\rho}(1-\theta) q^{\rho}$ \\
Vertical Integration & 0 & $A^{1-\rho}(1-\delta) \theta e^{\rho}+A^{1-\rho}(1-\theta) q^{\rho}$
\end{tabular}

The alternative organizational arrangement is (backward) vertical integration, in which $\mathrm{M}$ incorporates $\mathrm{S}$ as an internal unit (affiliate), hires the manager as the head of this unit and retains ownership of the assets in the event of no agreement. In this case, then, the multinational could fire the manager and replace him with someone else. This constitutes its threat point in the ex-post negotiations. We assume that this would occur at the cost of losing part of the value of the complex components, which would be reduced by a proportion $\delta<1$. As mentioned, the supplier's outside option is zero under vertical integration. Analytically, we obtain the expressions in the second line of the above table.

At this point, it is worth noting that the organizational form does not directly impact on the production function (there is no $a d$-hoc fixed cost of integration). It only directly affects the value of outside options.

\section{Financial constraints}

Lastly, an important feature of our model is the fact that capital markets are assumed to work only imperfectly. In particular, the supplier may be financially constrained at the 
time of starting to do business with the multinational firm. The multinational firm, on the other hand, is assumed to have access to both foreign and domestic financial markets and thus not to face liquidity constraints at all.

Limited available funds reduce the supplier's ability to make initial investments. More specifically, liquidity constraints impose a bound on the sum of initial costs $C$ and the upfront payment $T$ that can be asked initially by the multinational firm. Note that $T$ may be either positive or negative. Negative transfers reflect the extent of co-financing whereas positive transfers represent a participation fee (e.g. royalties or licensing fees for the use of the multinational's technology).

We assume that the supplier's level of initial liquidity is made up of two elements. One is initial holdings of cash, summed up by parameter $W$. In addition, the supplier can raise debt $L$ from local banks.

The fact that both the initial transfer $T$ and production costs $C$ are limited by available liquidity implies the following liquidity constraint:

$$
T+C \leq W+L
$$

How much the supplier can borrow from local banks depends on the level of financial development, indexed by a parameter $\kappa \in[0,1]$. Specifically, if the supplier's future revenues equal $Y_{S}$, the maximum amount of debt $L$ that can be raised from local banks is limited by the financial constraint:

$$
L \leq \kappa Y_{S}
$$

In other words, $\kappa$ is the ratio of pledgable income to total expected income. Thus, a value of $\kappa=1$ indicates perfect capital markets, whereas $\kappa=0$ indicates no capital market.

Various micro-economic theories can explain the presence of financial constraints. 
Models of credit rationing are based mainly on the non-observability of outcomes (for example, Aghion, et al. 1999; and Schneider and Tornell, 2004), investment decisions (Holmstrom and Tirole, 1997) and individual capabilities (Jaffe and Stiglitz, 1990). In keeping with ex-post moral hazard models, our variable $\kappa$ can be interpreted as the cost of diverting the funds and not repaying the debt. Alternatively, we could model financial development as the efficiency of monitoring to prevent unproductive decisions (Antras et al., 2009). With either approach, the conclusions of our model would remain qualitatively similar.

In the baseline specification, we assume that repayment of the debt is not contingent on whether an agreement is reached with the multinational firm. ${ }^{10}$ Note that we do not assume that vertical integration has a direct impact on the availability of external finance. For example, we could assume that stricter monitoring by the multinational firm allows for a higher level of debt from local banks. Such assumptions, however, yield very similar results regarding the choice between outsourcing and integration (as shown in Carluccio and Fally 2010a).

\section{Timing}

Before moving on to the solution of the model, we present the timing of events:

1. The multinational proposes a contract to the supplier specifying a triplet $(Z, T, q)$ where $Z$ is the organizational form, $T$ an upfront monetary transfer from $\mathrm{S}$ to $\mathrm{M}$ and $q$ the level of effort for the basic tasks. The upfront payment $T$ is restricted by the supplier's initial level of liquidity (debt and initial capital).

2. Transfer $T$ takes place.

3. The supplier decides its level of effort $e$ and produces the input, under the constraint that total cost can not exceed available liquidity. 
4. Nash bargaining on the value of joint production and repayment of the external debt take place.

\subsection{Solution}

\section{Maximization program}

The multinational's total profits equal its ex-post revenues plus the ex-ante transfer. The contract chosen maximizes total profits subject to three constraints: a participation constraint imposing non-negative total profits on the supplier, the financial constraints discussed previously, and an incentive compatibility constraint reflecting the supplier's decision in terms of specific investments in complex tasks.

In formal terms, $\mathrm{M}$ chooses the triplet $(Z, q, T)$ that solves the following constrained maximization problem:

$$
\begin{array}{lll}
\max & \Pi=Y_{M}^{Z}+T & \\
\text { Z,q,T } & & \\
\text { s.t. } & T \leq Y_{S}^{Z}-C & \text { (Participation constraint, PC) } \\
& T \leq W+\kappa Y_{S}^{Z}-C & \text { (Financial constraint, FC) } \\
& e=\operatorname{argmax}_{e}\left\{Y_{S}^{Z}-C\right\} & \text { (Incentive compatibility constraint, IC) }
\end{array}
$$

where $C=\theta c e+(1-\theta) c q$ is the cost of effort, and $\left\{Y_{M}^{Z}, Y_{S}^{Z}\right\}$ are revenues after bargaining. Ex-post revenues are functions of $e, q$ and the organizational form $Z \in\{O, I\}$ as we show in the next paragraph.

\section{Bargaining outcomes}

In the case of an outsourcing arrangement, the multinational's outside option equals revenues related to basic tasks, as production related to complex tasks is lost in the event of disagreement. Given symmetric bargaining power, ex-post revenues for the 
multinational firm and the supplier (before repayment of the debt) equal respectively:

$$
\begin{aligned}
& Y_{M}^{o}=\frac{1}{2} A^{1-\rho} \theta e^{\rho}+A^{1-\rho}(1-\theta) q^{\rho} \\
& Y_{S}^{o}=\frac{1}{2} A^{1-\rho} \theta e^{\rho}
\end{aligned}
$$

Under vertical integration, ex-post payoffs to both parties change in line with the new allocation of residual property rights. Given the effort put into the complex and basic tasks, the multinational firm captures a larger proportion of the ex-post revenues under integration while the opposite holds for the supplier:

$$
\begin{aligned}
Y_{M}^{I} & =\left(1-\frac{\delta}{2}\right) A^{1-\rho} \theta e^{\rho}+A^{1-\rho}(1-\theta) q^{\rho} \\
Y_{S}^{I} & =\frac{\delta}{2} A^{1-\rho} \theta e^{\rho}
\end{aligned}
$$

\section{Investments in complex and basic tasks}

In this framework, investments in specific tasks are determined by the organizational form. Under the incentive compatibility constraint (IC), investments made by the supplier in complex tasks maximize its ex-post revenues $Y_{S}^{Z}$ minus costs $C$, where $Z \in\{I, O\}$ refers to the organizational form. Under outsourcing, the level of effort equals:

$$
e^{o}(c)=a \rho(2 c)^{-\sigma}
$$

where $a=A \rho^{\sigma-1}$ is a constant and coefficient 2 in brackets comes from the symmetric Nash bargaining solution. The fact that the supplier's bargaining power is strictly below one implies that it does not recover the full marginal return on its investments. Thus, the level of non-contractible effort is below the first best even in cases where liquidity constraints do not bind.

Under integration, the supplier only retains a fraction $\frac{\delta}{2}$ of ex-post revenues in the bargaining stage. Given this, the optimal level of non-contractible effort is a function of 
the unit cost of effort and holds:

$$
e^{I}(c)=a \rho \delta^{\sigma}(2 c)^{-\sigma}<e^{o}(c)
$$

Efforts are lower than under outsourcing. The underinvestment problem is exacerbated because the supplier captures a smaller share of the ex-post surplus.

Compared to complex tasks, efforts in basic tasks are contractible and it can be easily shown that the first-best level is achieved, irrespective of the organizational choice:

$$
q^{o}(c)=q^{I}(c)=a \rho c^{-\sigma}
$$

Note that, in this simple framework, efforts are not directly affected by financial constraints for a given organizational structure. Moreover, efforts in complex and basic tasks do not interact and do not depend on the proportion of complex tasks. ${ }^{11}$

Given these expressions of the level of effort, computing ex-post revenues for each party is a straightforward exercise. The supplier's ex-post revenues are strictly lower under integration than under outsourcing. This is due to the smaller share of revenues obtained by the supplier in the bargaining stage and the lower value of production (efforts are lower

under integration). However, the multinational's ex-post revenues are not necessarily lower under integration as the multinational can capture a larger share of production value. $^{12}$

\section{Initial transfers: co-financing versus licensing fees}

The initial transfer $T$ plays a key role. In our set-up, $T$ is defined as a payment from the supplier to the multinational firm. Yet this payment can be negative, reflecting a monetary flow from the multinational to the supplier. In analytical terms, $T$ is determined by the participation constraint (PC) and the financial constraint (FC), which impose an 
upper bound on the level of the ex-ante transfer $T$.

When the financial constraint is slack, the ex-ante transfer is directly determined by equality in the participation constraint. This equals the supplier's ex-post revenues net of the costs of all tasks, and can be expressed as a function of marginal cost $c$ and complexity $\theta$. Under outsourcing, we obtain:

$$
\bar{T}^{o}(\theta, c)=a \theta\left(\frac{1-\rho}{2}\right)(2 c)^{1-\sigma}-a(1-\theta) \rho c^{1-\sigma}
$$

Under integration, the lower level of effort and the smaller share of revenues secured by the upstream firm call for lower ex-ante compensation to the multinational firm:

$$
\bar{T}^{I}(\theta, c)=\delta^{\sigma} a \theta\left(\frac{1-\rho}{2}\right)(2 c)^{1-\sigma}-a(1-\theta) \rho c^{1-\sigma}<\bar{T}^{o}(\theta, c)
$$

Both $\bar{T}^{o}$ and $\bar{T}^{I}$ can be either positive or negative and increase with the degree of complexity $\theta$ :

- When production relies essentially on basic tasks $(\theta=0)$, the multinational firm can finance all of the supplier's initial costs because there is no hold-up problem and it is able to capture all ex-post revenues. In this case, $T$ is strictly negative, reflecting an initial transfer from the multinational firm to the supplier (co-financing).

- Conversely, when production is complex and $\theta$ is closer to one, the supplier retains a larger share of the ex-post surplus. Instead of co-financing, positive ex-ante transfers are used to extract the supplier's rent when it exceeds the cost of initial investments (when the production technology is new and specific to the multinational, this payment can be interpreted as a licensing fee).

- The more complex production is, the greater the difference between outsourcing and integration in terms of optimal transfer (ownership only affects revenues and 
investments related to complex tasks).

At this point, it is quite intuitive that the supplier's access to finance will have a larger impact when there is a larger proportion $\theta$ of complex and non-contractible tasks. Moreover, financial constraints are less likely to affect the ex-ante transfer under integration compared to outsourcing, especially for complex tasks.

When are financial constraints binding? The financial constraint (FC) imposes an upper bound on the ex-ante transfer, depending on the debt from local banks and available liquidity. Formally, the financial constraint $(\mathrm{FC})$ is binding when the optimal transfer $\bar{T}^{Z}(\theta, c)$ does not satisfy the inequality in (FC). This occurs when initial capital is below a threshold $\bar{W}^{Z}(\theta, c, \kappa)$.

Under outsourcing, this threshold is:

$$
\bar{W}^{o}(\theta, c, \kappa)=\frac{1-\kappa}{2} a \theta(2 c)^{1-\sigma}
$$

The possibility of financial constraints being binding arises when the threshold is strictly positive, i.e. when the production of the input involves complex tasks $(\theta>0)$ and the financial markets are imperfect $(\kappa<1)$. The higher the complexity $\theta$ and the lower the level of financial development $\kappa$, the greater the likelihood of the financial constraint being binding, for a given $W$ - this is consistent with prior remarks on the level of optimal transfer.

Under integration, we obtain a smaller threshold:

$$
\bar{W}^{I}(\theta, c, \kappa)=\delta^{\sigma} \bar{W}^{o}(\theta, c, \kappa)<\bar{W}^{o}(\theta, c, \kappa)
$$

Financial constraints are less likely under integration because the multinational can retain a larger share of ex-post revenues and asks for less compensation. In addition, the value of production is lower than under outsourcing. 
Both wealth thresholds under integration and outsourcing decrease with the level of financial development:

$$
\frac{\partial \bar{W}^{Z}}{\partial \kappa}<0 \quad \text { for } Z \in\{I, O\}
$$

for $Z \in\{I, O\}$. Intuitively, financial constraints are less likely to be binding for suppliers in financially developed countries. This effect, however, depends on the type of input that is supplier. We obtain the following proposition:

Proposition 1. (i) The effect of financial development on the wealth threshold $\bar{W}^{Z}(\theta, c, \kappa)$ is stronger when production involves complex inputs:

$$
\frac{\partial^{2} \bar{W}^{Z}}{\partial \kappa \partial \theta}<0 \quad \text { for } Z \in\{I, O\}
$$

(ii) The threshold $\bar{W}^{Z}(\theta, c, \kappa)$ is higher under outsourcing: $\bar{W}^{O}(\theta, c, \kappa)>\bar{W}^{I}(\theta, c, \kappa)$.

In words, financial constraints are more likely to be binding for a low level of financial development, especially when production involves complex inputs. Moreover, financial constrains are more likely to be binding under outsourcing, compared to integration.

When the financial constraint is binding, the participation constraint (PC) is slack and the initial transfer $T$ is determined by the constraint (FC). Hence, when $W<\bar{W}^{o}(\theta, c, \kappa)$ under outsourcing, initial transfer $T$ depends on initial capital $W$ and the level of financial development $\kappa$ :

$$
T^{o}(W, \kappa, \theta, c)=W+a \theta\left(\frac{\kappa-\rho}{2}\right)(2 c)^{1-\sigma}-a(1-\theta) \rho c^{1-\sigma}<\bar{T}^{o}(\theta, c)
$$

Similarly, under integration we obtain:

$$
T^{I}(W, \kappa, \theta, c)=W+\delta^{\sigma} a \theta\left(\frac{\kappa-\rho}{2}\right)(2 c)^{1-\sigma}-a(1-\theta) \rho c^{1-\sigma}<\bar{T}^{I}(\theta, c)
$$


Naturally, when both initial capital $W$ and financial development $\kappa$ are low, we observe a lower transfer $T$. When $T$ becomes negative, it reflects the extent of co-financing when the supplier has little access to finance. Moreover, $T$ is more likely to be negative under integration, in which case $T$ can be interpreted as foreign direct investment. This result is consistent with Desai et al. (2004b) who find larger financial participation by multinationals in affiliates located in countries with poor financial markets.

\section{Multinational firm's profits}

In the benchmark case where $\mathrm{W}$ is large and capital markets are frictionless, the financial constraint (FC) is slack. The only restraint on the actions of the multinational firm is the necessity to ensure the supplier's participation (ensuring that the supplier gets nonnegative profits). In this case, the multinational is able to extract the entire surplus from the relationship and total profits equal total revenues $Y$ minus total costs $C$ :

$$
\begin{aligned}
& \bar{\Pi}^{o}(\theta, c)=a \theta\left(1-\frac{\rho}{2}\right)(2 c)^{1-\sigma}+a(1-\theta)(1-\rho) c^{1-\sigma} \\
& \bar{\Pi}^{I}(\theta, c)=\delta^{\sigma-1} a \theta\left(1-\frac{\delta \rho}{2}\right)(2 c)^{1-\sigma}+a(1-\theta)(1-\rho) c^{1-\sigma}
\end{aligned}
$$

Note that: $\bar{\Pi}^{o}(\theta, c)>\bar{\Pi}^{I}(\theta, c)$. In this case, the preferred organizational form is the one that maximizes non-contractible efforts by the upstream unit. Ex-post marginal benefits for the supplier are maximal when it remains independent, making outsourcing the optimal choice.

When the financial constraint is binding, the multinational is unable to extract the entire surplus. Profits equal the sum of ex-post revenues and initial transfer $T$, which is affected by the lack of initial capital $W$ or poor financial markets $\kappa$. Under outsourcing, the financial constraint is more likely to be binding (when $W<\bar{W}^{o}(\theta, c, \kappa)$ ), in which 
case we obtain:

$$
\Pi^{o}(W, \kappa, \theta, c)=W+a \theta\left(\frac{1+\kappa-\rho}{2}\right)(2 c)^{1-\sigma}+a(1-\theta)(1-\rho) c^{1-\sigma}
$$

Under integration, financial constraints may also be binding (when $W<\bar{W}^{I}(\theta, c, \kappa)$ ) and we obtain:

$$
\Pi^{I}(W, \kappa, \theta, c)=W+\delta^{\sigma-1} a \theta\left(\frac{2-\delta+\delta \kappa-\delta \rho}{2}\right)(2 c)^{1-\sigma}+a(1-\theta)(1-\rho) c^{1-\sigma}
$$

When financial constraints are binding, profits depend on both $\kappa$ and $\theta$. These profits are strictly lower than maximal profits when financial constraints are slack. Moreover, we can note that only revenues related to complex tasks are affected by financial constraints. Hence, the effects of financial constraints on the multinational firm's profits increase with the complexity of the tasks. Formally, we obtain the following proposition:

Proposition 2. When the financial constraint is binding, the multinational firm's profits increase with the level of financial development of the country in which the supplier operates, especially when production involves complex tasks:

$$
\frac{\partial \Pi^{Z}}{\partial \kappa}>0 \quad \text { and } \quad \frac{\partial^{2} \Pi^{Z}}{\partial \kappa \partial \theta}>0 \quad \text { for } Z \in\{I, O\}
$$

Proposition 2 complements Proposition 1, which also emphasizes the interaction between $\kappa$ and $\theta$, by highlighting how financial development and complexity affect the profitability of offshoring production. Financial development allows the multinational firm to recover ex ante the proportion of profits that are retained by the supplier. This proportion is higher the higher the complexity of production. Therefore, an increase in the level of financial development has a stronger impact on the multinational's profits when the intermediate good is more complex. Interestingly, financial development can 
have a negative impact on the supplier's profits because it reduces her rents, which are positive only when the financial constraint is binding.

\section{Financial constraints and organizational choice}

We can now roll back the clock to the moment when the multinational firm makes its decision about the optimal organizational form. Vertical integration is preferred when profits under outsourcing are lower compared to profits under integration.

Outsourcing is preferred to integration when financial constraints do not bind: $\bar{\Pi}^{o}(\theta, c)>$ $\bar{\Pi}^{I}(\theta, c)$, whatever $c$ and $\theta$. As already discussed, ownership delivers greater incentives to the supplier, and the value of the joint surplus can be recovered by the multinational firm through ex-ante payments, which are maximal in this case.

However, the possibility of obtaining ex-ante compensation vanishes as financial constraints start to bind under outsourcing. Conversely, financial constraints are less likely to bind under integration. When the financial constraint under integration is not binding $\left(W>\bar{W}^{I}(\theta, c, \kappa)\right)$ but initial capital is below a threshold $W^{I / O}(\kappa, \theta, c)$ defined implicitly by:

$$
\Pi^{o}\left(W^{I / O}, \kappa, \theta, c\right)=\bar{\Pi}^{I}(\theta, c)
$$

vertical integration becomes the preferred organizational form. By comparing expressions (6) and (7), we find the following expression for the threshold $W^{I / O}$ :

$$
W^{I / O}(\theta, c, \kappa)=a \theta(2 c)^{1-\sigma}\left[\delta^{\sigma-1}\left(1-\frac{\delta \rho}{2}\right)-\frac{1+\kappa-\rho}{2}\right]
$$

Moreover, we can show that the financial constraint is not binding under integration when the multinational firm is indifferent between outsourcing and integration. ${ }^{13}$ Formally, it implies that $W^{I / O}$ lies between $\bar{W}^{I}$ and $\bar{W}^{o}$ :

$$
\bar{W}^{I}(\theta, c, \kappa) \leq W^{I / O}(\theta, c, \kappa)<\bar{W}^{o}(\theta, c, \kappa)
$$


When initial capital is below $W^{I / O}$, vertical integration is chosen because its costs in terms of productive efficiency are outweighed by the larger fraction of ex-post surplus that the multinational retains under integration. Vertical integration thus emerges as a device to alleviate the negative effects of the supplier's financial constraints.

As shown in Propositions 1 and 2, financial constraints are strongest when the level of financial development is low and the degree of complexity is high. Hence, we find that $W^{I / O}$ is affected both by the level of financial development $\kappa$ and the complexity of production $\theta$, and also by their interaction. This property is a key feature of our model:

Proposition 3 The effect of financial development on the organizational threshold $W^{I / O}(\theta, c, \kappa)$ is negative and stronger when production involves complex inputs:

$$
\frac{\partial W^{I / O}}{\partial \kappa}<0 \quad \text { and } \quad \frac{\partial^{2} W^{I / O}}{\partial \kappa \partial \theta}<0
$$

The main intuition behind Proposition 3 is that vertical integration enables the multinational firm to retain a larger share of the ex-post surplus. Therefore, it reduces the need for ex-ante compensation and lessens the impact of the supplier's financial constraint when financial development is low and product complexity is high.

Note that vertical integration is more likely to arise in complex industries, because financial constraints are more likely to bind for complex goods:

$$
\frac{\partial W^{I / O}}{\partial \theta}>0
$$

Lastly, our results are not sensitive to hypotheses about the financial structure under integration. For various specifications about the availability of credit to the affiliated supplier, integration emerges in order to mitigate negative effects of financial constraints under outsourcing. For example, the same threshold $W^{I / O}$ is obtained if we assume 
perfect internal capital markets in the case of vertical integration (no financial constraint). Similarly, Proposition 3 remains true if we consider that the supplier is not able to raise any debt in the case of integration, since it is just an employee of the affiliated firm.

\subsection{Generalizations of the baseline model}

We now discuss two generalizations of the baseline model and show that its main implications carry on to more general settings. ${ }^{14}$

\section{Relationship-specific investments by the multinational}

In the baseline model, only the supplier undertakes relationship-specific investments affecting the value of the intermediate good. This assumption allows focusing on the incentives financial constraints provide for vertical integration in a simple framework. A consequence is that, absent financial constraints, there is no incentive for the firm to choose vertical integration. In this section, we present the main features of a generalization of the model with relationship-specific investments by the multinational and where vertical integration can be optimal even without financial constraints. Details are presented in Appendix A. We stress here that the main predictions of the baseline model relating financial development to profits and organizational forms continue to hold in this generalized version.

All of the features of the baseline model are preserved, except that now a share $0<\beta<1$ of complex tasks is assumed to be performed by the multinational firm. Hence, the fraction $\theta \beta$ represents the share of complex "headquarter services" in production (the baseline model corresponds to the particular case of $\beta=0$ ). Note that $\beta$ only refers to complex tasks. We could introduce a similar parameter for basic tasks, but the distribution of basic tasks between the two firms does not affect organizational choices. As we have seen in the baseline model, basic tasks are always performed at first-best 
levels.

Organizational forms are defined as the allocation of residual property rights: they affect incentives to invest to both parties by determining threat points in the ex post negotiation..$^{15}$

Under vertical integration the multinational firm retains ownership in case of disagreement, which enhances its ex ante incentives to invest. Conversely, vertical integration reduces the ex ante incentives of the supplier (in Appendix A we provide the ranking of effort levels across agents and organizational forms). When the financial constraint is slack, the multinational chooses the organizational form that maximizes joints surplus. A difference with the baseline model is that now the parameter $\beta$ influences optimal choices in this benchmark case. Intuitively, when $\beta$ is large, investment by the multinational is relatively more important for value creation. Vertical integration enhances its ex ante incentives to invest and arises as the optimal organizational mode. Conversely, a low value for $\beta$ implies that investment by the supplier matters relatively more for creating surplus. Outsourcing is then optimal. In the appendix we show that integration is the preferred organizational form if and only if $\beta$ is larger than a cutoff value $\beta^{I / O} \in(0,1)$. Because vertical integration alleviates financial constraints, integration still arises for $\beta>\beta^{I / O}$ when the financial constraint is binding.

When $\beta<\beta^{I / O}$, organizational forms are affected by financial constraints in the same vein as in the baseline model. The organizational threshold of supplier's wealth, the equivalent to expression (9), is now given by:

$$
W^{I / O}(\theta, c, \kappa)=a \theta(2 c)^{1-\sigma}\left[\beta(2-\delta)^{\sigma-1}\left(1-\rho+\frac{\delta \rho}{2}\right)+(1-\beta) \delta^{\sigma-1}\left(1-\frac{\delta \rho}{2}\right)-\frac{1+\kappa-\rho}{2}\right]
$$

It depends positively on $\beta$ : as the responsibility for specific investments switches from the supplier to the multinational, vertical integration becomes more likely (i.e. there is a wider range of values for $W$ where it is chosen). Comparative statics in terms of financial 
development $\kappa$ and product complexity $\theta$ are similar to those of the baseline model and satisfy the properties announced in Proposition 3.

\section{Contract enforcement and product complexity}

Thus far we have assumed that the share of complex tasks determines the extent of contract incompleteness. A more realistic setup would however need to take into account a second potential source of contractual frictions, determined by the efficiency of the legal system in enforcing contracts - commonly referred to as the "rule of law". Thus, more generally the share of noncontractible tasks might be thought to be a function of both technological and institutional characteristics: $\widetilde{\theta}(\theta, \tau)$ with $\widetilde{\theta}(\theta, \tau)$ being the "effective" share of non contractible tasks, $\tau$ a variable indexing the rule of law and $\theta$ refers to the technological complexity of the input. Naturally we assume: $\frac{\partial \widetilde{\theta}}{\partial \theta}>0$ and $\frac{\partial \widetilde{\theta}}{\partial \tau}<0$.

The baseline model could be re-written by replacing $\theta$ by $\widetilde{\theta}(\theta, \tau)$. It is straightforward to check that, under the assumptions just described of the function $\widetilde{\theta}(\theta, \tau)$, Propositions 1 to 3 would continue to hold.

Empirically, it tends to be the case that countries with low financial development also have low degrees of overall contract enforcement (La Porta et al, 2008). This would reinforce the effects we describe with our model. The need for external finance caused by contractual incompleteness would be exacerbated by a low rule of law, in those countries where access to external finance is harder. This would imply that financial constraints are even more likely to be binding.

This reduced form specification encompasses the following case: $\frac{\partial^{2} \widetilde{\theta}}{\partial \tau \partial \theta}<0$. This would correspond to the case where contract enforcement has a stronger impact on complex products (see Berkowitz et al, 2006 for evidence that countries with better contract enforcement develop a comparative advantage in complex products). Under this assumption we can obtain predictions in terms of the interactions between $\tau$ and $\theta$. In particular, multinationals should import relatively more complex products from countries with bet- 
ter contract enforcement. Bearing this in mind, in the empirical analysis we control for differences in the rule of law across countries interacted with product complexity. ${ }^{16}$

The impact of the interaction between contract enforcement and product complexity on organizational choice is more complex and results from the interaction of different effects. One the one hand, for a given degree of product complexity, low contract enforcement increases the need for finance, hence encouraging, ceteris paribus, vertical integration. One the other hand, a greater extent of contract incompleteness increases the need to provide investments incentives to the supplier, which is achieved through outsourcing. In a model as the one sketched in the previous subsection, the overall effect is ambiguous and depends on how contract enforcement affects the contractibility of activities carried out by each party. Antras and Helpman (2008) provides a good discussion of the general case. Following their results, in the empirical analysis we control for the interactions between the rule of law and product complexity and between different measures of headquarter intensity and product contractibility.

\subsection{Empirical Predictions}

The model's findings have direct implications in terms of optimal sourcing strategies. One of the main factors that lead firms to offshore production is the search for low labor costs, or low production costs in general. However, our model suggests that, while lower production costs point to choosing locations in developing countries, the profitability of this strategy could be affected by the financial capacity of suppliers and credit rationing by financial institutions. By emphasizing differential effects across industries, depending on the proportion of complex tasks to be undertaken by the supplier, our model shows that the effects of financial development are stronger in industries that are relatively more exposed to opportunism.

In the following, we illustrate some simple implications of the model in terms of 
sourcing strategies by considering the decision to import a product from a foreign country depending on the level of financial development, degree of complexity, and relative cost of producing the good in the foreign country.

Formally, we suppose that the multinational has the choice between two suppliers: one at home and one in a foreign country. We assume an imperfect capital market in the foreign country $\kappa<1$ but no financial friction at home. We normalize to one the unit cost of the home supplier and denote by $c<1$ the relative cost of the foreign supplier's effort. Hence, the home supplier has the advantage of no financial friction whereas the foreign supplier has lower effort costs.

In this framework, the multinational firm can make one of three choices: (i) no import (outsourcing from home supplier) ${ }^{17}$ (ii) outsourcing to a foreign supplier; (iii) sourcing from an integrated foreign supplier. Optimal strategies can be easily derived from expressions (5), (6) and (7). These choices are illustrated in Graphs 2a and 2b (see Appendix B for a formal derivation).

When the traded good relies mainly on basic tasks (Figure 2a), the foreign supplier's financial constraints are less likely to be binding and affect the multinational firm's profits (Propositions 1 and 2). Hence the multinational prefers to source inputs from abroad where production costs are lower even if the supplier has little access to finance.

Conversely, when production is intensive in complex tasks (Figure 2b), financial constraints are more likely to affect the multinational firm's profits (Propositions 1 and 2). When the foreign supplier is located in a country with poor financial institutions, the multinational will prefer to source inputs from home, unless there is a very large difference in production costs. Thus, we derive the following empirical prediction:

[Figure 2 about here]

Prediction 1 Multinational firms are more likely to import inputs from a country with a higher level of financial development. This effect is stronger for complex inputs. 
By emphasizing differences across industries, our model shows that financial development generates a comparative advantage in the supply of complex inputs.

This prediction contrasts with previous theoretical studies (e.g. Beck, 2002; Manova, 2008; Becker and Greenberg, 2007), suggesting that financial development generates a comparative advantage in sectors depending more heavily on external finance. The notion of dependence on external finance (Rajan and Zingales, 1998) is generally conceived as the need to finance initial costs before profits are generated, as opposed to sectors where initial costs are small and generated cash flows are sufficient to finance most investment. In our model, we account for the relationship between exporters and their customers who, for two-thirds of international trade flows, are multinational firms with broad access to liquidity. When production is intensive in basic tasks and there is no risk of hold-up from the supplier, financial development has little effect regardless of the level of initial costs.

Furthermore, our model can be used to make predictions about the sourcing mode: intra-firm or arm's length. In the case of basic goods (Figure 2a), outsourcing is the preferred organizational form for a wide range of parameters. In the case of complex goods (Figure $2 \mathrm{~b}$ ), outsourcing is the optimal strategy only when the foreign supplier is located in a country with high financial development. When production costs are very low but capital markets are poorly developed, it may still be profitable to import, but integration is chosen in order to alleviate the impact of financial constraints.

Prediction 2 Intra-firm trade is more likely when the supplier is located in a country with a lower level of financial development. This effect is stronger for complex inputs.

\section{Empirical Analysis}

In this section, we first describe the data and then test the main predictions of the model using a detailed firm-level dataset on international operations by multinational firms in 
France. First we analyze how financial development differently impacts the number of multinationals sourcing complex or basic inputs across countries. We also study how the volume of aggregate and firm-level imports in complex and basic goods responds to the level of financial development. Finally, we examine whether imports tend to occur within the firm depending on a country's financial development and product complexity.

\subsection{Data description}

\section{SESSI Database}

Our analysis is based on a firm-level survey in France by SESSI (French Office of Industrial Studies and Statistics). The survey covers firms that trade more than one million euros and belong to manufacturing groups holding at least $50 \%$ of a foreign affiliate's equity capital.

The survey provide trade flows detailed by firm, product and country of origin or destination. Products are classified using both the four-digit CPA (Classification of Products by Activity) and four-digit harmonized system. Due to the availability of other data, we work at the three-digit level of the CPA classification which corresponds precisely to the NACE Rev1 classification (also closer to the ISIC Rev3 three-digit classification). Throughout the paper, and for simplicity in exposition, we use the word "product" to refer to the classification of the imported good. Notice that it might not be the same as the main good produced and sold by the multinational firm (which we refer to as the "industry").

The data cover $55 \%$ of total French imports, spread among 4,305 firms. ${ }^{18}$ For our analysis, we focus solely on manufacturing imports and countries with available data on financial development and our main controls (Table 8 in the appendix provides the list of countries corresponding to positive imports). We obtain a dataset on 3,957 importing firms, 52,617 cells by firm, product and country with positive imports. ${ }^{19}$ 
In addition to total value, the data provide information on the proportion of trade flows with an independent supplier or affiliate firm for each multinational, country and product. By definition, the trading partner is considered to be a subsidiary when the multinational controls at least $50 \%$ of the equity capital. Around half of French imports are intra-firm, which is approximatively the same as the share of intra-firm imports in the US (Antras, 2003). ${ }^{20}$

\section{Financial development variables}

Our main explanatory variable is the level of financial development, measured by the amount of credit from banks and other financial institutions to the private sector as a share of GDP (private credit). This index reflects the financial depth of the economy and the capacity to provide external financing. The variable is drawn from Beck et al. (2000). It ranges from 1.3\% for Angola to 201\% for Japan (see Figure 1). It is highly correlated with alternative measures of financial development (stock market capitalization, accounting standards, interest rate margin, bank regulation, investor protection, etc.). It has been used extensively as a measure of financial development (Rajan and Zingales, 1998; King and Levine, 1993). Alternatively, we use the net interest margin as an alternative measure of the efficiency of the banking sector (source: Beck et al, 2000). We also use an index of accounting standards (La Porta et al, 1998) as an example of a measure more directly related to regulations.

\section{Product complexity variables}

Our main measure of product complexity is an index of R\&D intensity. Since we focus on French firms' offshoring decisions, we measure R\&D intensity using French data. The use of R\&D intensity indices with French data implicitly assumes either that the technology can be transferred to the supplier (and is thus similar to the technologies in France) or that industry ranking in terms of technological content varies little from one country to 
the next. Firm-level data on R\&D expenditure are taken from the 1999 Third Community Innovation Survey (CIS 3). Indices are constructed for each three-digit NACE classification with at least ten observations. We can use three measures: (i) total industry R\&D expenditure to total sales; (ii) the percentage of firms in the industry with positive R\&D expenditure; (iii) the 75th percentile of $R \& D$ expenditure to sales for firms in the industry. We focus on the latter because it is less sensitive to measurement errors, but we checked that all measures yield similar results. ${ }^{21}$ Table 1 provides the list of products associated with the highest R\&D intensities. Not surprisingly, computers, precision instruments and aircraft correspond to the most complex industries. In opposition, a few have a zero index of R\&D intensity (e.g. cutting and shaping of stone, manufacture of wooden conteners, preparation and spinning of textile fibres).

In the working paper version Carluccio and Fally (2010a) we perform a set of regressions using R\&D intensity constructed in the same way from CIS data on firms in the United Kingdom. This tests whether we are picking up on a French industry particularity (the French and English indices are correlated at 57\% with a Spearman rank correlation of $63 \%)$.

In the model, complex goods are defined as goods with a large range of tasks that are firm-specific and cannot be described in a contract. Complexity lies at the heart of the incomplete contracts literature, as established by the seminal work of Grossman and Hart (1986). ${ }^{22}$ In this regard, our preferred measure is R\&D intensity for several reasons. First, R\&D is associated with the production of complex products and processes. This makes codifiability and verifiability of information a much harder and more expensive task. Hence, firms in R\&D-intensive sectors are more likely to be unable to describe all specifications in contracts. Second, a R\&D intensive product is often new and not standardized, which makes it difficult to specify in advance. A firm may also be reluctant to do so for strategic reasons. ${ }^{23}$ Moreover, one of the main motives for R\&D is to accumulate specific knowledge helping firms to create differentiated products. Therefore, 
R\&D intensity may also reflect product specificity. Lastly, R\&D may not be performed in order to create new products or processes, but to adapt existing technologies to different contexts (Cohen and Levinthal, 1989). Even in this case, higher R\&D intensity reflects the difficulty to assimilate the technology and closely relates to efforts in complex tasks in the model.

[Table 1 about here]

As an alternative, we use the Rauch (1999) classification. In Rauch (1999), products are either differentiated, traded on organized exchanges or reference priced. The latter two categories are often referred to as homogeneous goods and the former as heterogeneous goods. We thus construct an index that equals one for differentiated goods and zero otherwise. This index can be used to some extent to differentiate complex from basic products, but it is often interpreted as a measure of contract intensity: differentiated products (which are neither traded on organized exchanges nor reference priced) cannot be easily substituted and are relationship-specific. Taking this interpretation, Nunn (2007) shows that better contract enforcement, measured by the rule of law variable, generates a comparative advantage in industries that rely intensively on differentiated inputs. As we focus on the comparative advantage in supplying inputs rather than final goods, a notable difference with Nunn (2007) is that we directly interact the rule of law variable with the Rauch index using the traded input's product classification. ${ }^{24}$

Other indices can be used, such as indices of technological content which are expected to be highly correlated with R\&D intensity and yield similar results. ${ }^{25}$

Table 2 presents the mean and standard deviations of the main variables. Definitions and sources of control variables are presented in the data appendix.

[Table 2 about here] 


\subsection{Financial development and the geography of imports}

\section{Empirical strategy}

The model predicts that, other things being equal, multinational firms prefer to import complex inputs from financially developed countries (Prediction 1). This points to a differential effect between complex and basic goods and naturally calls for a differencein-difference approach (pioneered by Rajan and Zingales, 1998).

We use two main dependent variables. For each country/product cell we calculate the number of multinationals reporting positive imports, as well as the value of total imports. The first variable corresponds to the extensive margin of trade (Yeaple, 2009).

Table 4 presents the basic statistics drawn from the data, revealing strong correlations between the country of origin's level of financial development (private credit) and the number of firms importing from this country. The correlation is stronger for R\&Dintensive goods, in line with the differentiated effect described in the model: over $50 \%$ for products with high R\&D intensity (above the median) compared to $38 \%$ for other products. Conversely, the correlation between the number of importers and level of complexity is stronger for countries above the financial development median than for countries below the median. Similar differences in correlation coefficients are observed when looking at aggregated imports instead of the number of importers. These statistics suggest that financial development impacts on the composition of exports to multinational firms depending on R\&D intensity.

[Table 3 about here]

In the following econometric investigation, we analyze the determinants of the number of firms $N_{c p}$ that import inputs from country $c$ in product $p$ (based on classification $p$ of imports) and the value of total trade flows from country $c$ in product $p$. In particular, we want to test whether the financial development of country $c$ has a differential effect 
depending on the complexity of traded good $p$. The difference-in-difference approach includes country dummies that control for any observable or unobservable country characteristics that do not affect the export's level of complexity. It also includes product dummies to control for product characteristics that do not affect the origin of the imports.

Our preferred dependent variable is the number of firms $N_{c p} \cdot{ }^{26}$ We assume that firms' choices depend on a set of variables $X_{c p}$. These variables include a set $\tilde{X}_{c p}$ of observed product and country characteristics, but we also allow for unobserved determinants. Specifically, we suppose that the probability that a firm imports a product $p$ from country $c$ is an exponential function of country fixed effects, product fixed effects, an interaction term between financial development and input complexity, a set of controls and the unobserved effect. Conditional on the type of product $p$ and the source country $c$, we have:

$$
P\left(\text { Import } \mid X_{c p}\right)=\exp \left[\beta .\left(\text { FinDevt }_{c} * \text { Complexity }_{p}\right)+\gamma \cdot \text { Controls }_{c p}+\eta_{c}+\zeta_{p}+\lambda_{c p}\right]
$$

where FinDevt is $_{c}$ the level of financial development of country $c$, Complexity the level of complexity of product $p, \eta_{c}$ a country fixed effect, $\zeta_{p}$ an product fixed effect and $\lambda_{c p}$ an unobserved effect. Taking the aggregate number of importers by country and product, it follows that, up to a constant $N$ :

$$
E\left[N_{c p} \mid X_{c p}\right]=N \cdot \exp \left[\beta .\left(\text { FinDevt }_{c} * \text { Complexity }_{p}\right)+\gamma \cdot \text { Controls }_{c p}+\eta_{c}+\zeta_{p}+\lambda_{c p}\right]
$$

Conditionally on the mean $E\left[N_{c p} \mid X_{c p}\right]$, we assume that the number of importers follows a Poisson distribution. The Poisson distribution can be justified by taking the limit of a Bernouilli law for a large number of firms. However, conditionally on the set of observed characteristics $\tilde{X}_{c p}$, the distribution deviates from the Poisson distribution because of the unobserved component $\lambda_{c p}$. Assuming that this term is an i.i.d. random effect 
following a gamma distribution with coefficient $1 / \alpha$ (with variance $\alpha$ ), it can be shown that the number of importers follows a Negative Binomial distribution (see Cameron and Trivedi, 1998) with law:

$$
P\left(N_{c p}=n \mid \tilde{X}_{c p}\right)=\frac{\Gamma\left(n+\alpha^{-1}\right)}{n ! \Gamma\left(\alpha^{-1}\right)} \frac{\alpha^{-(1 / \alpha)} \mu^{n}}{\left(\mu+\alpha^{-1}\right)^{n+\alpha^{-1}}}
$$

where $\mu=E\left[N_{c p} \mid \tilde{X}_{c p}\right]$. Moreover, the conditional variance is given by $\operatorname{Var}\left[N_{c p} \mid \tilde{X}_{c p}\right]=$ $\mu(1+\alpha \mu)$. When the random effect $\lambda$ has zero variance $(\alpha=0)$, the variance of $N_{c p}$ equals the (conditional) mean and the distribution is Poisson. When $\alpha$ is strictly positive, the distribution is said to be overdispersed.

Equation (10) is estimated under Maximum Likelihood (see Cameron and Trivedi, 1998). This can also be used to estimate $\alpha$, assuming that it does not depend on the expected mean $\mu$ (NegBin II specification). Note that Ordinary Least Square regressions (taking the log of the dependent variable) are not suitable for count data, especially when a significant number of product/country cells have no importer (two-thirds of our observations).

As in OLS regressions, the identification of our main coefficient relies on the assumption of orthogonality between the interaction term and the residual $N_{c p}-E\left[\hat{N}_{c p} \mid \tilde{X}_{c p}\right]$. However, given the inclusion of the full set of country and product dummies, this estimation strategy is not sensitive to the exclusion of controls that are not correlated with financial development or do not affect trade differently depending on the complexity of inputs. Therefore, we are mainly concerned with variables potentially correlated with financial development and that may impact on complex goods industries in particular.

Another set of regressions uses the value of imports by product and country of origin instead of the number of importers. Santos Silva and Tenreyro (2006) argue that OLS inconsistency may also apply. Thus, we follow the same specification as for the number of importers and estimate Negative Binomial regressions for the value of imports. Yet, 
the value of imports does not only reflect the decision to source product $p$ from country $c$ but also captures other characteristics of transactions such as the scale of production and the price of the traded good. These other aspects may also be affected by financial development and product complexity, as shown in Section 3.3. Therefore, we primarily focus on regressions using the number of importers. ${ }^{27}$

In all the tables, we report robust standard errors corrected for clusters by country because our main variable FinDevt s $_{c}$ only varies across countries. The coefficients can be interpreted as semi-elasticities, as they measure the impact of the right-hand-side variable on the log of the (expected) number of importers. ${ }^{28}$

\section{Results on the number of importers and total trade flows}

In Table 4, we analyze the interaction term between product complexity and financial development for different measures of complexity, including our main controls. In column (1), financial development is interacted with our benchmark index of complexity: R\&D intensity measured with French firm-level data. This yields a positive and significant coefficient, a result in line with Prediction 1: financial development is a source of comparative advantage in the supply of complex inputs.

Our control variables include capital and skill endowments interacted with capital and skill intensity. They enter positively and significantly, in keeping with the HeckscherOhlin model of trade. Two other important controls, rule of law and patent protection, are positively correlated with financial development and may potentially affect sourcing strategies. In line with the recent literature on institutions and trade (Nunn, 2007; Levchenko, 2007; Acemoglu, Antras and Helpman, 2007), judicial quality and better contract enforcement generate a comparative advantage in complex industries that rely more intensively on contracts. In our regression, rule of law is interacted with the Rauch (1999) index of differentiated goods versus homogeneous goods, often interpreted as an index of contract intensity. We find a positive interaction term, which confirms the 
results obtained by Nunn (2007) and Berkowitz et al (2006). Patent protection, our proxy for intellectual property rights, is interacted with the index of R\&D intensity, as R\&D-intensive industries rely more intensively on patents. However, we do not find that stronger intellectual property rights favor trade in R\&D-intensive inputs. ${ }^{29}$

Our result is also robust to the alternative measures of complexity. In column (2), we use the Rauch (1999) index of differentiated goods versus homogeneous goods (contract intensity), which also yields a positive and significant coefficient for the interaction term. Interestingly, the rule of law coefficient becomes insignificant, suggesting that financial development has the strongest impact. ${ }^{30}$

Beck (2003) and Manova (2006 and 2008) use world trade data by country and sector to show that financial development generates a comparative advantage in sectors that are more dependent on external finance. These studies use the measure of financial dependence developed by Rajan and Zingales (1998), constructed as the share of investment not financed by cash flows, taking the median across US listed firms in the sectors.

Our model, however, suggests that the dependence of multinationals' suppliers on external finance is specifically related to contract incompleteness and increases with their production complexity. As both indices of financial dependence and technological complexity are positively correlated (at 20\%), we need to check that our results are not driven by the Rajan and Zingales (1998) index of financial dependence.

In column (3), we therefore control for the interaction term between financial development and financial dependence. We also control for an interaction between financial development and capital intensity. Capital intensity can be interpreted as an index of headquarter intensity (Antras, 2003). Another index of headquarter intensity (value added over sales across industries) is also included into the regression. In line with our model, only the interaction term between financial development and complexity is positive and significant while the other interaction terms taking in financial development are not statistically significant. Qualitatively, the same results are obtained using the Rauch 
(1999) index instead of R\&D intensity.

Columns (4) to (6) confirm the results when the dependent variable is the value of imports. We find that the effect of financial development is also significant. The main coefficient is slightly less significant using R\&D intensity (column 4 and 6) and more significant using Rauch (1999) index (column 5). Overall, the results are qualitatively similar to those using the number of importers.

In all regressions specifying a Negative Binomial distribution for the residual, the estimated coefficient $\alpha$ is approximately 0.5 when the dependent variable is the number of importers and 10 when the dependent variable are trade flows. As we can expect, overdispersion is greater for trade flows. In both cases, the likelihood-ratio test for $\alpha=0$ (corresponding to the Poisson distribution) is rejected. ${ }^{31}$ It shows that the residual's variance is strictly larger than the mean, which implies that the residual does not follow a Poisson distribution (overdispersion). In unreported regressions, we check alternative specifications to verify that our results do not depend on our assumptions regarding the error term distribution. We obtain similar results with Poisson regressions. Alternatively, we can estimate OLS regressions (in order to accommodate for zeros we can use the logarithm of one plus the number of importers as the dependent variable).

These results confirm that the country of origin's financial development is strongly correlated with the number of multinational firms importing complex inputs compared to basic inputs, or the volume of trade flows for these products. But how sizeable is the effect of financial development? In view of our estimation approach, we consider the effect of financial development by comparing two industries that differ in one standard deviation in terms of $R \& D$ intensity. Using the coefficient of the interaction term, we estimate the differential effect of a one standard deviation change in financial development on the number of multinational firms importing complex inputs. Given the coefficient in column (1) of Table 4, we obtain a differential effect of $9 \%$ on the number of importers. This effect is large and is comparable to the effect of skill endowment on the number of importers (dif- 
ferential effect of $18 \%$ by comparing low- and high-skill-intensive industries). Moreover, the estimated effect of financial development is stable across the different specifications as in in column (2) of Table 4 (10\% with the Rauch index). By comparison, the rule of law effect is larger if we take the column (1) estimation, but smaller taking column (2) in Table 4.

In columns (4) to (6), the magnitude of the effect of financial development is even larger. As we confirm in Section 3.3, financial development also affects the scale of imports (intensive margin), which can explain why its effect on the total value of trade is quantitatively larger.

[Table 4 about here]

\section{Other robustness checks}

In Table 5, we perform further robustness checks. In column (1), we check that our results are robust to the inclusion of other controls. In particular, we might still be concerned with whether financial development captures the effect of an alternative country characteristic with a different impact on complex and basic products. We thus interact rule of law with R\&D intensity in the place of the Rauch index. The new interaction term with rule of law is not significant. It confirms that rule of law yields the strongest effect under the Rauch (1999) measure of contract intensity. We control for the interaction of skill endowments with the index of $\mathrm{R} \& \mathrm{D}$ intensity in addition to the interaction with skill intensity, but the corresponding coefficient is not significant. We can also include an interaction between R\&D intensity and per capital GDP (in log). Although financial development is positively correlated with income level, the new interaction term is not significant and the coefficient for financial development remains unchanged. Thus, our results are not generated by the level of overall development rather than financial development. ${ }^{32}$ 
An argument that can be advanced is that countries with technological advantages in sectors that rely relatively more on external finance will tend to develop their financial systems to exploit these advantages. Our work, however, focus on multinationals' suppliers. There is extensive evidence that these firms benefit from technology transfers by multinationals (Caves, 2007) and operate different technologies from local firms. ${ }^{33}$ Hence, omitting controls on the local technology is unlikely to bias our results. We account for this by controlling for human capital interacted with R\&D intensity (column 1 of Table 5). This reflects the assumption that the costs of technology transfers vary across countries depending on the extent of their capacity to absorb foreign technologies.

In columns (2) and (3), we check that our results are robust to alternative measures of financial development. We use a measure of the net interest rate margin in column (2) and an index of accounting standards in column (3). The former provides an alternative measure of the (in)efficiency of the banking sector while the latter directly reflects financial regulations. The results indicate strong interaction terms between complexity and both indicators, with the expected signs.

The right half of the table shows that results are qualitatively similar when the dependent variable is the value of imports. Consistently with the results in Table 4, our main coefficient is slightly less significant but its magnitude is larger.

We perform additional robustness checks in Appendix D. In particular, we test whether our results are sensitive to the identification of intermediate goods, as opposed to goods that are not further processed by the importer. Moreover, we test whether our results are not driven by the presence of export platforms by restricting to groups with headquarters in France.

We have also carried out a set of further robustness checks which are available upon request. We restricted the sample to contain only large firms (above 500 employees). We obtain coefficients and standard errors similar to those with the full sample, reducing the potential concern of a large number of small firms driving the results. ${ }^{34}$ 
One could argue that exporting opportunities for local firms in sectors dependent on external finance increase the demand for credit and hence foster the development of the financial sector. Do and Levchenko (2007) rationalize this mechanism. They build a simple model to show that greater foreign demand in financially dependent industries leads to larger volumes of credit and more developed financial markets. Based on the estimated effect of geographic variables on trade volumes across sectors, they construct a country-level variable that predicts the value of external finance need of exports. They report a substantial correlation between this variable and financial development. Using this variable, we can show that our results are not driven by the interaction between complexity and geographical determinants of financial development (see Carluccio and Fally, 2010a).

With cross-sectional data, one way to check the direction of causality is to use an instrument for financial development which does not directly impact on exports. Legal origin provides an exogenous variable that meets these requirements. In particular, common-law countries are better financially developed than civil-law countries. Nevertheless, it has also been shown to have a strong effect on various other aspects of institutional quality (Djankov et al., 2007; La Porta et al. 2008). Nunn (2007) proposes a simple way to isolate the effect on financial development by matching civil and common law countries with similar characteristics in control variables. In unreported estimations, we apply a similar method and find a strong and positive effect of common law on the composition of exports in complex products, after matching countries by rule of law, level of intellectual property rights protection and factor endowments (results available upon request).

[Table 5 about here]

Finally, we have checked that our results are not sensitive to minor product or country sample changes. For example, the coefficient remains equally similar when we drop countries with less than one million inhabitants, African countries, OECD countries or Asian 
tigers. Neither is the coefficient sensitive to dropping private credit or R\&D intensity percentiles either end of the scale.

\subsection{Financial development and the scale of imports}

So far, we have tested Prediction 1 by looking at the impact of financial development and input complexity on the number of importers and total trade volumes by country and product. We can also use our firm-level data to test whether financial development has a differential impact on firm-level imports of complex products. To some extent, effects on firm-level trade flows correspond to the intensive margin of imports whereas effects on the number of importers correspond to the extensive margin. Specifically, we can estimate:

$$
\log \left(M_{c p i}\right)=\beta .\left(\text { FinDevt }_{c} * \text { Complexity }_{p}\right)+\gamma \cdot \text { Controls }_{c p}+\eta_{c}+\zeta_{p}+\phi_{i}+\varepsilon_{c p i}
$$

where $\phi_{i}$ is a fixed effect by firm. This is estimated for all observations by firm, country and product with positive trade flows. Specifications (11) and (12) are estimated by a simple OLS. We continue to report robust standard errors corrected for clusters by country.

Table 6 presents our findings. There is no firm dummy in column (1), but firm fixed effects are systematically included in columns (2) to (4). The results show that financial development has a significant impact on firm-level imports. A comparison of columns (1) and (2) shows that controlling for firm dummies does not affect the financial development coefficient.

[Table 6 about here]

We perform the same robustness checks as for the previous tables. In column (3), we check that our financial development findings are not driven by the interaction with external finance dependence, capital intensity and headquarter intensity measured in 
the corresponding sector in France. Although the interaction with capital intensity is significant at 5\%, the main coefficient remains unchanged. In column (4), we interact rule of law with the $R \& D$ intensity index in the place of the Rauch index of contract intensity: the coefficient for rule of law is not significant whereas the coefficient for credit remains. Moreover, our results are robust to controlling for the interaction terms between skill endowments, per capita GDP and R\&D intensity.

Table 6 results show that the impact of financial development on the import of complex inputs carries over different specifications and different margins. It affects not only the number of importers, but also total imports and firm-level imports. Quantitatively, financial development has less of an effect on firm-level imports (column 1 of Table 6) than on the number of importers (column 1 of Table 4). Consistently, the sum of these effects approximatively equals the effect on total imports (column 4 of Table 4).

\subsection{Financial development and sourcing mode}

We now investigate the model's theoretical predictions with regards to the relationship between financial constraints and optimal organizational mode. Our theory predicts that integration is preferred to trade with independent suppliers when financial constraints are strong and trade involves complex products with inputs requiring a larger proportion of specific, non-contractible investments (Prediction 2). To provide evidence of this statement, the following econometric analysis uses as its dependent variable the share of intra-firm imports by firm for each product-country pair. ${ }^{35}$

Table 3 presents some descriptive statistics. It shows that the correlation between our measure of financial development and the share of intra-firm imports is substantially stronger in the case of complex goods (Panel A). Conversely, the correlation between the average share of intra-firm imports and R\&D intensity is stronger in countries with low financial development. However, these correlations might be driven by the effects of 
variables other than financial development, such the general level of contract enforcement. So the above simple correlations, although informative, could be misleading. ${ }^{36}$

In order to overcome this problem, we take a similar approach to the previous section and focus our analysis on interaction terms. In this case, we also look at variations in financial development across countries and variations in complexity across industries. As already mentioned, this strategy is appealing because it has the advantage of controlling for all product- and country-specific characteristics that we do not observe and that might affect intra-firm shares. In order to be sure that we are picking up the effect of financial development, we control for several alternative interaction terms.

The empirical strategy we employ is in line with the difference-in-difference approach taken in the previous section. More specifically, our estimating equation is given by:

$$
I_{c p i}=\beta .\left(\text { FinDevt }_{c} * \text { Complexity }_{p}\right)+\gamma \cdot \text { Controls }_{c p}+\alpha_{i}+\eta_{c}+\zeta_{p}+\varepsilon_{c p i}
$$

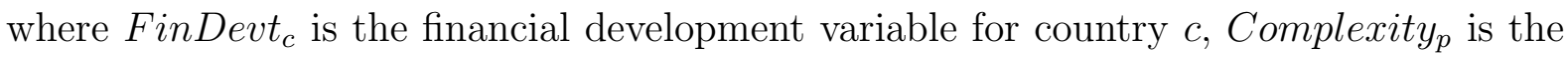
complexity index for traded input $p$, and $\alpha_{i}, \eta_{c}$ and $\zeta_{p}$ are fixed effects by firm, country and product respectively. Thus, our identification strategy focuses on within-firm variations in sourcing modes across product-country cells. We estimate the above equation using Ordinarily Least Squares (OLS) and report robust standard errors with correction for clusters by country. One potential problem with estimating (12) by OLS is that our dependent variable is defined as a share and is therefore bounded between zero and one. To account for this, we can also estimate the model under a fractional Logit specification and obtain very similar results. As a robustness check, we provide results from the estimation of a conditional Logit model using only "pure" organizational strategies (i.e. when the share of intra-firm trade in an product-country cell is either 100\% or zero). Note, however, that such an approach potentially loses valuable information, as around $13 \%$ of our observations are mixed. 
Results are presented in Table 7. The coefficient of main interest is, as before, the interaction between financial development and complexity. As can be seen from column (1), the coefficient is negative and significant. This result is robust to the inclusion a full set of country, product and firm fixed effects, which are included in all regressions presented in this section.

We obtain very similar coefficients for financial development whether firm dummies are included or not. It implies that the effects we are picking up are not due to any unobserved firm characteristics that may impact systematically on the choice between intra-firm and arm's length trade - for example, Antras and Helpman (2004 and 2008) predict that more productive firms tend to trade relatively more within the firm than less productive firms. ${ }^{37}$

[Table 7 about here]

In addition, as can be seen from the table, all the regressions include the following set of controls. First, the index of patent protection is interacted with R\&D intensity. Multinational firms may prefer to source complex inputs from an affiliate in order to reduce technological imitation and appropriation by local competitors, and these forces might be stronger in environments where intellectual property rights are weakly enforced. This coefficient is however not significant in most specifications. Secondly, we control for judicial quality, interacted with the Rauch index. Foreign firms' internalization decisions may be affected by the quality of judicial system; rule-of-law effects could arguably be greater in contract-dependent industries. This coefficient is positive in all specifications, consistent with the findings of Defever and Toubal (2008) for French firms. In addition, its inclusion does not affect the relevance of the financial development variable. Lastly, all of our regressions include controls for traditional comparative advantage determinants, interacting capital intensity and skill intensity at product level with capital and skill endowments at country level respectively. Note that we have chosen to report results 
from regressions including all of these controls together in order to limit the number of columns. Yet our results remain the same when we add one control at a time, and are similar when we exclude firm fixed effects. ${ }^{38}$

We perform various robustness checks to ensure that it is really the interaction of financial development and R\&D intensity that drives the intra-firm share effects on which we report. In column (2), we use the Rauch index and obtain significant coefficients with the expected signs. This result indicates that trade is more likely to occur with an affiliate when financial development is low and the product is more specific. In column (3), we interact financial development with other product characteristics. It might be argued that if complex industries are more dependent on external finance, then our results might be picking up the effect of external finance dependence instead of complexity. In column (3), the inclusion of the interaction between financial development and the external finance index confirms that this is not the case. In the same column, we include an interaction term between financial development and capital intensity. Capital intensity may reflect the size of the industry's fixed costs or the intensity in headquarter services (as argued in Antras 2003). We also use an alternative index of headquarter intensity construsted from the ratio of value added over sales in the corresponding industry in France. None of these controls turns out to be significant.

In column (4), we address other important questions by including three additional controls. We first include an interaction between the rule-of-law measure and R\&D intensity. This coefficient is not significant, while the interaction between financial development and R\&D intensity remains negative and significant. Therefore, our results on the impact of financial development on the share of intra-firm trade are not driven by the overall level of contract enforcement. Secondly, we interact rule of law with capital intensity. The coefficient is negative, but not statistically different from zero; note that its sign is in line with the prediction by Antras and Helpman (2008) and the empirical results of Bernard et al (2010). Thirdly, we may be concerned with whether financial development, measured 
by private credit to GDP, is endogenous to the intensity of foreign direct investment in the country. However, we show that the inclusion of a measure of restrictions on foreign investors does not alter our result. Note that we obtain a similar result when controlling directly for FDI inflows.

Finally, column (5) presents the results of the conditional Logit estimation, including firm fixed effects and other controls, from which mixed strategies are dropped (the dependent variable is thus either equal to zero or unity). Again, the sign and level of significance of our coefficient of interest are in line with Prediction 2.

We also perform robustness checks on the estimating sample. We run the above regressions minus Asian, African and small countries (less than one million inhabitants) and obtain the same results. Our results are robust to the elimination of one country at a time (obtaining even stronger results when we drop Japan and the USA, which have the highest ratios of private credit to GDP). In Appendix D we examine narrower definitions of intermediate imports and restrict our sample to groups with headquarters in France. We find similar and even stronger results.

\section{Conclusion}

In recent years, international trade literature has devoted substantial efforts to understand the role of institutions in shaping trade patterns. In this paper, we propose a new mechanism driven by an interaction between financial development and the extent of contract incompleteness. We argue that suppliers' financial constraints exacerbate the hold-up problem and impact on multinational firms' optimal sourcing strategies. These effects are stronger in complex industries characterized by higher degrees of contract incompleteness. Further, the model shows that vertical integration alleviates financial constraints, albeit at the cost of lower efforts and productivity.

The model generates two novel predictions. First, we predict that financial develop- 
ment creates a comparative advantage in the supply of complex products. Second, we should observe higher shares of intra-firm trade in complex products from countries with a low level of financial development. These predictions are tested using detailed firm-level data on the international operations of multinational firms located in France. We use a difference-in-difference approach, which allows for the inclusion of country and product fixed effects. A one standard deviation increase in the level of financial development yields an increase of $9 \%$ in the number of multinational firms importing complex goods compared to basic goods, an increase of $7 \%$ in the volume of firm-level imports and a decrease of $3 \%$ in the share of intra-firm trade. ${ }^{39}$ These results are robust to different measures of the complexity and specificity of the traded goods, to alternative measures of the level of financial development and to the inclusion of firm fixed effects among other controls. The estimated effect of financial development appears to be as large as that of contract enforcement.

As pointed up by the model, the positive effect of financial development on international trade is not limited to isolated exporters but carries over into multinationals' suppliers. Multinational firms are known to play an important role in the transfer of technologies to suppliers located in less developed countries, where the adoption of technologies constitutes a major source of productivity growth. One implication of our model is that suppliers located in countries with poor financial institutions are less likely to acquire new technological knowledge to produce complex products. This mechanism may explain, for example, why the presence of multinational firms has a stronger impact on growth in countries with better financial institutions (Alfaro et al., 2004). 


\section{Notes}

${ }^{1}$ About $67 \%$ of French imports and $75 \%$ of French exports in 1999 concerned manufacturing groups controlling at least $50 \%$ of a foreign affiliate. Similar patterns are observed for the US. Moreover, one-third of world trade is intra-firm (UNCTAD 2002). This proportion is even higher for developed countries: nearly half of US trade occurs within firms' boundaries.

${ }^{2}$ Hart and Moore (1999) and Segal (1999) present theoretical grounds for the existence of incomplete contracts by incorporating the notion of complexity.

${ }^{3}$ Figure 1: World trade flows in manufacturing goods in 1999 are drawn from CEPII at the 2-digit level of ISIC Revision 3. According to the OECD STAN definition of high and medium-high technology manufactures, complex industries correspond to codes 24 and 29 to 35 (more refined measures are used in the empirical section). Financial development is measured as the ratio of private credit to GDP (Beck et al., 2000). We focus on the 100 largest countries in terms of population with data on private credit. The coefficient of the linear trend is 0.366 (std error: 0.033).

${ }^{4}$ In the working paper version Carluccio and Fally (2010a) we show results are robust to the use of other measures of complexity: R\&D intensity measured in the UK and the Lall (2000) index of technological content

${ }^{5}$ Kletzer and Bardhan (1987) is the first theory on financial development and trade, where better financial institutions generate a comparative advantage in financially dependent sectors.

${ }^{6}$ The intensity in headquarter services is defined as in Antras (2005). However, Basco (2008) does not consider the choice between outsourcing and integration.

${ }^{7}$ The main predictions made by Antras (2003) and Antras and Helpman (2004, 2008) have been empirically checked by Yeaple (2006), Nunn and Trefler (2008), and Bernard et al. (2008) using data on US multinational firms and by Defever and Toubal (2007) and 
Corcos, Irac, Mion and Verdier (2008) using the SESSI dataset on French multinational firms, which we also use in our empirical analysis. However, none of them considers the level of financial development.

${ }^{8}$ Note that the linearity in $\theta$ in the expression for $Y$ comes from the equality between both elasticities of substitution. In Carluccio and Fally (2010a) we discuss a more general framework and show that our main mechanisms remain. Nevertheless, in the general case it is not possible to obtain closed-form solutions. Similar linear forms have been put forward by Acemoglu, Aghion, Griffith and Zilibotti (2010) and Acemoglu, Johnson and Mitton (2009). Alternatively, we can obtain such a linear expression by assuming that only one task has to be performed, characterized by a probability $1-\theta$ of being verifiable and a probability $\theta$ of being non-verifiable. In this specification, the results would remain qualitatively similar.

${ }^{9}$ Our model would remain qualitatively unchanged if we were to relax the assumption of symmetry. In Carluccio and Fally (2010a), we look at the case where efforts in complex tasks are not fully specific and improve the supplier's outside option (e.g. efforts of technology assimilation), which yields similar conclusions to the baseline model. In a similar framework, Feenstra and Hanson (2005) estimate a bargaining power of 0.7 for the multinational firm and 0.3 for the local firm. These values, however, are not statistically different from 0.5 .

${ }^{10}$ In Carluccio and Fally (2010a), we also explore the alternative route and assume that repayment of the debt depends on the agreement between the supplier and the multinational. Whether the debt is raised from the multinational firm or from local banks makes no difference in the baseline specification. However, raising debt from local is optimal when repayment of the debt is contingent on an agreement with the multinational firm.

${ }^{11}$ The baseline model's main findings are robust to alternative structures. In Carluccio and Fally (2010a), the first extension of the model allows for a positive outside option for 
the supplier. In some cases, where outside options are large, investments in complex efforts are constrained by available liquidity and do not maximize the supplier's ex-post revenues. The last extension of the model examines a more general framework and discusses a generalization of our results when efforts in complex and basic tasks are interdependent.

${ }^{12}$ The multinational's ex-post revenues are higher under integration when $\rho<1 / 2$ and $\delta$ is close enough to one.

${ }^{13}$ In extreme cases of high financial development with a sharp drop in the level of efforts under integration, integration does not arise regardless of $W$. Formally, this happens when $\delta^{\sigma-1} \frac{2-\delta+\delta \kappa-\delta \rho}{2}<\frac{1+\kappa-\rho}{2}$.

${ }^{14}$ As already mentioned, three other generalizations are discussed in the working paper version: (i) on the role of supplier outside options; (ii) on interactions between debt and ex post bargaining; (iii) on more general production functions.

${ }^{15}$ Throughout the paper we take a "property rights" approach to the firm (Grossman and Hart, 1986; Hart and Moore, 1990). We acknowledge that the literature has identified other motives leading firms to vertically integrate. Theoretical surveys on the subject can be found in Holmstrom and Roberts (1998) and Gibbons (2005). In a comprehensive survey of both theory and applied work, Lafontaine and Slade (2007) point out that the most common approaches to backward integration and the "make-or-buy decision" (the case under study here) are transaction cost and property rights models. As discussed there, the main predictions of these models, which are preserved in our framework, have received robust empirical support.

${ }^{16}$ We could also deliver predictions in terms of the interaction of $\kappa$ and $\tau$. The empirical identification of such effects is made difficult by the high correlations between these two country-level variables. We choose not to focus on them.

${ }^{17}$ As financial constraints are not binding for the home supplier, outsourcing is preferable. More general results could be obtained by assuming imperfect capital markets at home, but the main predictions would hold as long as the home supplier has better access 
to finance.

${ }^{18}$ The survey covers $82 \%$ of trade flows involving multinational firms operating in France. Note also that the quality of the SESSI survey has been checked by statistical offices using data from other sources. The trade flows are consistent with customs data and the intra-firm trade flows consistent with data on the location of the French affiliate (INSEE Financial Links Survey (LIFI), Bank of France and French General Treasury and Economic Policy Directorate (DGTPE) data).

${ }^{19}$ Indices on skill and capital intensity are not available for the food and beverages industry (ISIC 15). Note that our findings are not sensitive to the inclusion of this sector when these variables are excluded from the regressions.

${ }^{20}$ US Census and Customs data (resp. BEA data) consider the partner to be a "related party" when the multinational has 6\% (resp. 10\%) of the shares but does not necessarily control the firm. In practice, however, majority-owned affiliates (equity shares of 100\%) are largely dominant. Desai et al. (2004b) use the Bureau of Economic Analysis' annual survey of U.S. direct investment abroad and show that in 1997 wholly-owned affiliates accounted for $80 \%$ of total foreign affiliates of US firms. Majority-owned affiliates (with equity shares of the American parent between $50 \%$ and 100\%) accounted for 9\%, and minority-owned ones (with equity shares of the American parent between $10 \%$ and $50 \%$ ) for the remaining $11 \%$.

${ }^{21}$ The 75 th percentile is preferred to the median to reduce the number of zeros (industries where over half the firms do not do $R \& D)$.

${ }^{22}$ The model developed by Grossman and Hart (1986) is based around the key assumption that "[production decisions]...are sufficiently complex that they cannot be specified completely in an initial contract between the firms". In later work, Hart and Moore (1999) and Segal (1999) develop this idea further by providing theoretical foundation to incomplete contracts, around the notions of complexity and renegotiation.

${ }^{23}$ Specification of the characteristics of new product and processes makes them easier to 
imitate as codification facilitates technological leakage at the innovator's expense (Caves, 2007).

${ }^{24}$ Nunn (2007) focuses on comparative advantage in terms of output. He thus constructs an alternative index equivalent to the Rauch (1999) index weighted by the coefficient of the US input-output matrix.

${ }^{25}$ In the working paper version we use an index constructed from the Lall (2000) classification.

${ }^{26}$ Using similar firm-level data for the US, Yeaple (2009) also chooses to focus on this indicator in his analysis of the structure of US foreign investment.

${ }^{27}$ We also verifies that our results on the number of importers are not driven by small firms by estimating the same equation using large firms only.

${ }^{28}$ The interaction term should be interpreted as a cross derivative of the logarithm of the predicted number of importers, which is linear in the right-hand-side variables. Note also that our fixed effects subsume all direct effects of country- and product-level variables, and thus we do not need to control for direct effects.

${ }^{29}$ These results hold when complexity is measured using UK data on R\&D or the Lall (2000) index, as shown in Carluccio and Fally (2010a).

${ }^{30}$ This result, however, needs to be interpreted with caution as the correlation between both indices of financial development and rule of law is over $50 \%$.

${ }^{31}$ This test does not account for heteroskedasticity, but the P-value is lower than 0.001 .

${ }^{32}$ Moreover, we should note that the inclusion of R\&D intensity index interactions with distance, language and colonial links does not affect our main result (not reported).

${ }^{33}$ In Carluccio and Fally (2010b) we analyze the effects of technological incompatibilities between foreign and domestic technologies on spillovers and technology adoption.

${ }^{34}$ The fact that results are robust to using the value of imports also reduces this potential concern, as more weight is put on large firms.

${ }^{35}$ Our data is disaggregated at product level, so we are unable to observe the value and 
sourcing mode governing the relationship with each particular supplier. Our productlevel data consequently contains "mixed" trade flows, where the same product has been imported by the same firm by means of both intra-firm trade and outsourcing.

${ }^{36}$ Acemoglu et al (2009) show that simple cross-country comparisons may be driven by product composition. Once product fixed effects are included in their regressions, the direct effects of institutional quality on the organizational mode are generally not significant.

${ }^{37}$ Defever and Toubal (2007) and Corcos et al. (2008) test this prediction using the same dataset.

${ }^{38}$ In unreported estimates, we also control for the interaction between per capita GDP and complexity to check whether we are indeed picking up the level of overall development rather than a financial channel. This interaction term comes out positive, but not significant.

${ }^{39}$ Based on a comparison of goods that differ by one standard deviation in their level of complexity. 


\section{References}

[1] Acemoglu, Daron, Philippe Aghion, Rachel Griffith, and Fabrizio Zilibotti, "Vertical integration and technology: theory and evidence," Journal of the European Economic Association, 85:5 (2010), 1-45.

[2] Acemoglu, Daron, Pol Antras, and Elhanan Helpman, "Contracts and Technology Adoption," American Economic Review, 97:3 (2007), 916-943.

[3] Acemoglu, Daron, Simon Johnson and Todd Mitton, "Determinants of Vertical Integration: Finance, Contracts and Regulation," Journal of Finance, 63:3 (2009), 1251-1290.

[4] Aghion, Philippe, Abijit Banerjee and Thomas Piketty "Dualism and macroeconomic volatility," Quarterly journal of economics, 114:4 (1999), 1359-1397.

[5] Aghion Philippe, and Patrick Bolton, "An Incomplete Contracts Approach to Financial Contracting," Review of Economic Studies 59:3 (1992), 473-494.

[6] Aghion Philippe, Thibault Fally, and Stefano Scarpetta, "Credit Constraints as a Barrier to the Entry and Post-Entry Growth of Firms: Lessons from Firm-Level Cross Country Panel," Economic Policy, 22 (2007), 731-779.

[7] Aghion, Philippe, and Jean Tirole, "On the Management of Innovation," Quarterly journal of economics, 109:4 (1994), 1185-1209.

[8] Alfaro, Laura, Areendam Chanda, Sebnem Kalemli-Ozcan and Selin Sayek, "FDI and Economic Growth: The Role of Local Financial Markets," Journal of International Economics, 64:1(2004), 89-112.

[9] Antras, Pol "Firms, Contracts, and Trade Structure," Quarterly Journal of Economics, 118:4 (2003), 1375-1418. 
[10] Antras, Pol "Incomplete Contracts and the Product Cycle," American Economic Review, 95:4 (2005), 54-1073.

[11] Antras, Pol, Mihir Desai, and Fritz Foley "Multinational Firms, FDI Flows and Imperfect Capital Markets," The Quarterly Journal of Economics, 124:3 (2009), 1171-1219.

[12] Antras, Pol, and Elhanan Helpman, "Global Sourcing," Journal of Political Economy, 112:3 (2004), 552-580.

[13] Antras, Pol, and Elhanan Helpman, "Contractual Frictions and Global Sourcing," in Elhanan Helpman, Dalia Marin, and Thierry Verdier (Eds.) The Organization of Firms in a Global Economy (Cambridge MA: Harvard University Press, 2008).

[14] Antras, Pol and Esteban A. Rossi-Hansberg, "Organizations and Trade," Annual Review of Economics, 1, (2009), 43-64.

[15] Basco, Sergi, "Financial Development and the Product Cycle," MIT mimeo (2008).

[16] Beck, Thorsten, "Financial Development and International Trade. Is There a Link?" Journal of International Economics 57 (2002),107-31.

[17] Beck, Thorsten, "Financial Dependence and International Trade," Review of International Economics 11(2003), 296-316.

[18] Beck, Thorsten, Ash Demirguc-Kunt, and Ross Levine, "A New Database on Financial Development and Structure," World Bank Economic Review, 14 (2000), 597-605.

[19] Bernard, Andrew, J. Bradford Jensen, Stephen J. Redding and Peter K. Schott, "Intra-Firm Trade and Product Contractibility," American Economic Review, Papers and Proceedings, 100:2 (2010), 444-448.. 
[20] Berkowitz, Daniel, Johannes Moenius, and Katharina Pistor, "Trade, Law and Product Complexity," this Review, 88:2 (2006), 363-373.

[21] Caves, Richard E. (2007), Multinational Enterprise and Economic Analysis, Third Edition (Cambridge UK: Cambridge University Press, 1996).

[22] Cameron, A. Colin and Pravin K. Trivedi, Regression Analysis of Count Data, Econometric Society Monograph No.30, Cambridge University Press, 1998.

[23] Campa, Jose M., and Linda Goldberg, "The Evolving External Orientation of Manufacturing Industries: Evidence from Four Countries," Federal Reserve Bank of New York Economic Policy Review 4 (1997), 79-99.

[24] Carluccio, Juan and Thibault Fally, "Global Sourcing under Imperfect Capital Markets," CEPR discussion paper no. 7868 (2010a).

[25] Carluccio, Juan and Thibault Fally, "Foreign Entry and Spillovers with Technological Incompatibilities in the Supply Chain," CEPR Discussion Paper 7869 (2010b).

[26] Chaney, Thomas, "Liquidity Constrained Exporters," University of Chicago mimeo $(2005)$.

[27] Cohen, Wesley M. and Daniel A Levinthal, "Innovation and Learning: The Two Faces of R\&D," Economic Journal, 99:397 (1989), 569-96.

[28] Corcos, Gregory, Delphine M. Irac, Giordano Mion, and Thierry Verdier, "The Determinants of Intra-Firm Trade", Universite Catholique de Louvain, mimeo (2008).

[29] Costinot, Arnaud, "On the Origins of Comparative Advantage," Journal of International Economics, 77:2 (2009), 255-264. 
[30] Defever, Fabrice and Farid Toubal, "Productivity and the Sourcing Modes of International Firms: Evidence from French Firm-Level Data," CEP discussion paper no. $842(2007)$.

[31] Desai, Mihir A., C. Fritz Foley, and James R. Hines, Jr., "A Multinational Perspective on Capital Structure Choice and Internal Capital Markets," The Journal of Finance 59:6 (2004a), 2451-2488.

[32] Desai, Mihir A., C. Fritz Foley, and James R. Hines, Jr., "The costs of shared ownership: Evidence from international joint ventures," Journal of Financial Economics 73: 2 (2004b), 323-374.

[33] Do, Quy-Toan. and Andrei Levchenko "Comparative Advantage, Demand for External Finance, and Financial Development," Journal of Financial Economics, 86:3 (2007), 796-834.

[34] Dixit, Avinash. K., and Joseph. E. Stiglitz, "Monopolistic Competition and Optimum Product Diversity," American Economic Review, 67:3 (1977), 297-308.

[35] Djankov, Simeon, Caralee McLiesh, and Andrei Shleifer, "Private Credit in 129 Countries," Journal of Financial Economics, 84 (2007), 299-329.

[36] Ethier, Wilfred, and James Markusen, "Multinationals, Technical Diffusion, and Trade," Journal of International Economics 41(1996), 1-28.

[37] Feenstra, Robert C., "Integration of Trade and Disintegration of Production in the Global Economy," The Journal of Economic Perspectives, 12:4 (1998), 31-50.

[38] Feenstra, Robert C., and Gordon H. Hanson. "Globalization, Outsourcing, and Wage Inequality", American Economic Review Papers and Proceedings, $96: 2$ (1996), 24045 . 
[39] Feenstra, Robert C., and Gordon H. Hanson, "Ownership and Control in Outsourcing to China: Estimating the Property Rights Theory of the Firm", Quarterly Journal of Economics, 120:2 (2005), 729-762.

[40] Gibbons, Robert "Four Formal(izable) Theories of the Firm", Journal of Economic Behavior and Organization, 58 (2005), 200-245.

[41] Ginate, Juan C. and Walter G. Park, "Determinants of Patent Rights: A CrossNational Study," Research Policy, 26:3 (1997) 283-301.

[42] Gourieroux, Christion, Alain Monfort, and Alain Trognon "Pseudo Maximum Likelihood Methods: Applications to Poisson Models" Econometrica, 52: 3 (1984), 701720.

[43] Grossman, Sandford. and Oliver Hart, "The Costs and Benefits of Ownership: A Theory of Vertical and Lateral Integration," Journal of Political Economy 94:4 (1986), 691-719.

[44] Hall, Robert and Charles Jones "Why do Some Countries Produce So Much More Output per Worker than Others?" Quarterly Journal of Economics, 114(1999), 83116.

[45] Hart, Oliver, and John Moore, "Property Rights and the Nature of Firms," Journal of Political Economy 98:6 (1990), 1119-58.

[46] Hart, O. and Moore, J. (1999) "Foundations of Incomplete Contracts," Review of Economics Studies, 66, pp. 115-138.

[47] Holmstrom, Bengt, and Jean Tirole, "Financial Intermediation, Loanable Funds, and the Real Sector," Quarterly Journal of Economics, 112:3 (1997), 663-69. 
[48] Hummels, Davis, Jun Ishii and Kei-Mu Yi, "The Nature and Growth of Vertical Specialization in World Trade," Journal of International Economics, 54:1(2001), 7596.

[49] Jaffe, D. M., and Joseph Stiglitz "Credit Rationing" in Benjamin M. Friedmann and Frank H. Hahn (eds.), Handbook of Monetary Economics II (Amsterdam: Elsevier Science Publishers, 1990).

[50] Kaufmann, Daniel, Aart Kraay, and Massimo Mastruzzi, "Governance Matters III: Governance Indicators for 1996-2002," World Bank Working Paper 3106 (2003).

[51] King, Robert G., and Ross Levine "Finance and Growth: Schumpeter Might Be Right" Quarterly Journal of Economics, 108:3 (1993), 717-738.

[52] King, Robert G., and Ross Levine, "Finance, Entrepreneurship, and Growth: Theory and Evidence," Journal of Monetary Economics ,32:3(1993), 513-542.

[53] Klapper, Leora, Luc Laeven, and Raghuram Rajan "Entry Regulation as a Barrier to entrepreneurship", Journal of Financial Economics, 82(2006), 591-629.

[54] Kletzer, Kenneth, and Pranab Bardhan, "Credit Markets and Patterns of International Trade," Journal of Development Economics, 27 (1987), 57-70.

[55] Lafontaine, Francine and Margaret Slade, "Vertical Integration and Firm Boundaries: The Evidence," Journal of Economic Literature,45:3 (2007), 631-687.

[56] La Porta, R., F. Lopez-de-Silanes, and A. Shleifer "The Economic Consequences of Legal Origins," Journal of Economic Literature, 46:2 (2008), pp. 285-332.

[57] La Porta, Rafael., Florencio Lopez-de-Silanes, and Andrei. Shleifer, "Law and Finance," Journal of Political Economy, 106:6(1998),1113-1155. 
[58] Lall, Sanjaya. (2000), "The technological structure and performance of developing country manufactured exports, 1985-98," Oxford Development Studies, 28(3).

[59] Legros, Patrick. and Andrew Newman "Competing for Ownership," Journal of the European Economic Association, 6(2008), 1279-1308.

[60] Levchenko, Andrei, "Institutional Quality and International Trade" Review of Economic Studies, 74:3 (2007), 791-819.

[61] Macchiavelo, Rocco, "Financial Development and Vertical Integration: Theory and Evidence," Journal of the European Economic Association, forthcoming.

[62] Manova, Kalina. "Credit Constraints, Heterogeneous Firms and International Trade," Stanford University, mimeo(2006).

[63] Manova, Kalina "Credit Constraints, Equity Market Liberalizations and International Trade," Journal of International Economics, 76:1(2008), 33-47.

[64] Manova, Kalina, Shang-Jin Wei and Zhiwei Zhang "Firm Exports and Multinational Activity under Credit Constraints," Standford University mimeo (2009).

[65] Nunn, Nathan, "Relationship Specificity, Incomplete Contracts and the Pattern of Trade," Quarterly Journal of Economics,122:2 (2007), 569-600.

[66] Nunn, Nathan and Daniel Trefler "The Boundaries of the Multinational Firm: An Empirical Analysis," in Elhanan Helpman, Dalia Marin, and Thierry Verdier (Eds.) The Organization of Firms in a Global Economy (Cambridge MA: Harvard University Press, 2008).

[67] Rajan, Raghuram and Luigi Zingales . "Financial Dependence and Growth," American Economic Review 88 (1998),559-86. 
[68] Rauch, James E., "Networks Versus Markets in International Trade," Journal of International Economics 48:1 (1999), 7-35.

[69] Santos Silva, Joao, and Silvana Tenreyro, "The Log of Gravity," Review of Economics and Statistics 88:4 (2006), 641-658.

[70] Schneider, M. and Tornell, A. "Balance Sheet Effects, Bailout Guarantees and Financial Crises," Review of Economic Studies 00(2004), 1-31

[71] Segal, Ilya, "Complexity and Renegotiation: A Foundation for Incomplete Contracts," Review of Economic Studies 66 (1999), 57-82

[72] UNCTAD World Investment Report (2002), Geneva.

[73] Yeaple, Stephen "Offshoring, Foreign Direct Investment, and the Structure of U.S. Trade," Journal of the European Economic Association, 4:2-3 (2006), 602-611.

[74] Yeaple, Stephen, "Firm Heterogeneity and the Structure of U.S. Multinational Activity," Journal of the European Economic Association, 65:1(2009), 1-20.

[75] Yeats, Alexander (2001), "Just How Big is Global Production Sharing?" in Sven W. Arndt and Henryk Kierzkowski (eds.), Fragmentation: New Production Patterns in the World Economy, Oxford University Press.

\section{Appendix A: Derivation of the model with relationship-specific investments by the multinational}

In this framework, investments in specific tasks are determined by the organizational form. Under the incentive compatibility constraint (IC), investments made by the supplier in 
complex tasks maximize its ex-post revenues $Y_{S}^{Z}$ minus costs $C$, where $Z \in\{I, O\}$ refers to the organizational form. Under outsourcing, the level of effort equals:

$$
e_{M}^{o}(c)=e_{S}^{o}(c)=a \rho(2 c)^{-\sigma}
$$

where $a=A \rho^{\sigma-1}$ is a constant and coefficient 2 in brackets comes from the symmetric Nash bargaining solution.

Under integration, the supplier only retains a fraction $\frac{\delta}{2}$ of ex-post revenues in the bargaining stage, whereas the buyer retains a fraction $\frac{2-\delta}{2}$. Given this, the optimal level of non-contractible effort is a function of the unit cost of effort and holds:

$$
\begin{gathered}
e_{S}^{I}(c)=a \rho \delta^{\sigma}(2 c)^{-\sigma}<e_{S}^{o}(c) \\
e_{M}^{I}(c)=a \rho(2-\delta)^{\sigma}(2 c)^{-\sigma}>e_{M}^{o}(c)
\end{gathered}
$$

Efforts are lower than under outsourcing for the supplier but large than outsourcing for the multinational.

As before, efforts in basic tasks are contractible and it can be easily shown that the first-best level is achieved, irrespective of the organizational choice and irrespective of who implements the effort:

$$
q_{S}^{o}(c)=q_{S}^{I}(c)=q_{M}^{o}(c)=q_{M}^{I}(c)=a \rho c^{-\sigma}
$$

\section{Multinational firm's profits and organizational choice}

Let $\beta \in[0,1]$ denote the share of complex tasks to be performed by the buyer.

In the benchmark case where $\mathrm{W}$ is large and capital markets are frictionless, the financial constraint (FC) is slack. The only restraint on the actions of the multinational firm is the necessity to ensure the supplier's participation (ensuring that the supplier gets 
non-negative profits). In this case, the multinational is able to extract the entire surplus from the relationship and total profits equal total revenues $Y$ minus total $\operatorname{costs} C$ :

$$
\begin{aligned}
& \bar{\Pi}^{o}(\theta, c)=a \theta\left(1-\frac{\rho}{2}\right)(2 c)^{1-\sigma}+a(1-\theta)(1-\rho) c^{1-\sigma} \\
& \bar{\Pi}^{I}(\theta, c)=\beta(2-\delta)^{\sigma-1} a \theta\left(1-\rho+\frac{\delta \rho}{2}\right)(2 c)^{1-\sigma}+(1-\beta) \delta^{\sigma-1} a \theta\left(1-\frac{\delta \rho}{2}\right)(2 c)^{1-\sigma}+a(1-\theta)(1-\rho) c^{1-\sigma}
\end{aligned}
$$

We find that integration is preferred to outsourcing $\left(\bar{\Pi}^{I}(\theta, c)>\bar{\Pi}^{o}(\theta, c)\right)$ whenever:

$$
\beta>\beta^{I / O} \equiv \frac{1-\frac{\rho}{2}-\delta^{\sigma-1}\left(1-\frac{\delta \rho}{2}\right)}{(2-\delta)^{\sigma-1}-2 \rho\left(1-\frac{\delta}{2}\right)^{\sigma}-\delta^{\sigma-1}\left(1-\frac{\delta \rho}{2}\right)}
$$

We can verify that $\beta^{I / O}$ lies strictly between zero and one.

Moreover, when $\beta>\beta^{I / O}$ integration is preferable to outsourcing whatever the strength of financial constraints. When $\beta<\beta^{I / O}$ and the financial constraint is binding under outsourcing, the wealth threshold becomes:

$$
W^{I / O}(\theta, c, \kappa)=a \theta(2 c)^{1-\sigma}\left[\beta(2-\delta)^{\sigma-1}\left(1-\rho+\frac{\delta \rho}{2}\right)+(1-\beta) \delta^{\sigma-1}\left(1-\frac{\delta \rho}{2}\right)-\frac{1+\kappa-\rho}{2}\right]
$$

This threshold follows the same properties described in Proposition 3.

\section{Appendix B: Derivation of Figure 2}

Figure 2 plots optimal strategies in the $\left(c^{\sigma-1}, \kappa\right)$ plane. The frontiers between regions are derived by equating profits under the two relevant strategies and solving for the pairs of $\left(c^{\sigma-1}, \kappa\right)$ for which equality holds. Equality between profits from outsourcing in the home country ("No import") and outsourcing in the foreign country ("Outsourcing") is given by: 


$$
c_{1}^{\sigma-1}=\frac{a \theta\left(\frac{1+\kappa-\rho}{2}\right) 2^{1-\sigma}+a(1-\theta)(1-\rho)}{a \theta\left(1-\frac{\rho}{2}\right) 2^{1-\sigma}+a(1-\theta)(1-\rho)-W}
$$

with $\frac{\partial c_{1}^{\sigma-1}}{\partial \kappa}>0 ; \quad \frac{\partial c_{1}^{\sigma-1}}{\partial \theta}<0 ; \frac{\partial^{2} c_{1}^{\sigma-1}}{\partial \kappa^{2}}=0 ; \frac{\partial^{2} c_{1}^{\sigma-1}}{\partial \kappa \partial \theta}>0$.

Equality between profits from Outsourcing and Integration in the foreign country are given by:

$$
c_{2}^{\sigma-1}=\frac{a \theta 2^{1-\sigma}}{W}\left[\delta^{\sigma-1}\left(1-\frac{\delta \rho}{2}\right)-\left(\frac{1+\kappa-\rho}{2}\right)\right]
$$

with $\frac{\partial c_{1}^{\sigma-1}}{\partial \kappa}>0 ; \frac{\partial c_{1}^{\sigma-1}}{\partial \theta}<0 ; \frac{\partial^{2} c_{1}^{\sigma-1}}{\partial \kappa^{2}}=0 ; \frac{\partial^{2} c_{1}^{\sigma-1}}{\partial \kappa \partial \theta}>0$.

Finally, the figure assumes for the sake of simplicity that financial constraints are not binding under integration. In this case the frontier between the "No import" and "Integration" regions is given by

$$
c_{3}^{\sigma-1}=\frac{\theta\left(1-\frac{\delta \rho}{2}\right) \delta^{\sigma-1} 2^{1-\sigma}+(1-\theta)(1-\rho)}{\theta\left(1-\frac{\rho}{2}\right) 2^{1-\sigma}+a(1-\theta)(1-\rho)-W}
$$

with $\frac{\partial c_{2}^{\sigma-1}}{\partial \kappa}=0 ; \frac{\partial c_{2}^{\sigma-1}}{\partial \theta}>0 ; \quad \frac{\partial^{2} c_{2}^{\sigma-1}}{\partial \kappa^{2}}=0 ; \quad \frac{\partial^{2} c_{2}^{\sigma-1}}{\partial \kappa \partial \theta}<0$.

When instead the financial constraint is binding at a point where the multinational firm is indifferent between outsourcing at home and integration of the foreign supplier, we have:

$$
c_{4}^{\sigma-1}=\frac{a \theta\left(\frac{2-\delta+\kappa \delta-\rho \delta}{2}\right) 2^{1-\sigma} \delta^{\sigma-1}+a(1-\theta)(1-\rho)}{a \theta\left(1-\frac{\rho}{2}\right) 2^{1-\sigma}+a(1-\theta)(1-\rho)-W}
$$

with $\frac{\partial c_{4}^{\sigma-1}}{\partial \kappa}>0 ; \quad \frac{\partial c_{4}^{\sigma-1}}{\partial \theta}>0 ; \quad \frac{\partial^{2} c_{4}^{\sigma-1}}{\partial \kappa^{2}}=0 ; \quad \frac{\partial^{2} c_{4}^{\sigma-1}}{\partial \kappa \partial \theta}<0$. 


\section{Appendix C: Data sources}

The index of financial dependence we use is drawn from Klapper, Leaven and Rajan (2007). It is constructed using the ISIC Revision 3 classification from Compustat data on US firms, in keeping with the Rajan and Zingales (1998) methodology. Financial dependence is defined as one minus the ratio of cash flow to investment, taking the average across years for a given firm (the 1990s) and the median across firms in the sector.

Skill and physical capital endowments are interacted with indices of skill and capital intensity. Assuming perfect labor markets and homogeneous firms, differences in skill intensities across industries are reflected by differences in wages. Using the Annual Manufacturing Survey on French firms (Enquête Annuelle d'Entreprises) which covers all firms with more than 20 employees, we construct our index of skill intensity as the median (in $\log$ ) of the distribution of average wages across firms. ${ }^{40}$ Similarly, we use the median (in $\log$ ) of the distribution of the capital labor ratio across firms in the industry as a proxy for capital intensity. Notice that capital intensity could also be interpreted as a proxy for the size of fixed costs and headquarter intensity (Antras, 2003).

In addition, we use the Annual Manufacturing Survey to construct two additional indices. For each industry, we take the median of firm size in the industry (in log) as well as the median of value added over sales. The latter is commonly interpreted as an index of vertical integration or headquarter intensity.

[Table 8 about here] 


\section{Appendix D: Robustness checks on the identification of vertical trade and supply chains}

In this appendix we present results from robustness checks regarding the identification of vertical supply chains. Following the methodology adopted by Feenstra and Hanson (1996), we drop imports of goods that are classified in the same category as the main product of the importing business unit within the group (and thus we drop business units of manufacturing groups that are not primarily classified as manufacturing). As can be seen in the odd columns of Table 9, we observe that our main coefficient remains unchanged under this specification, and it sometimes become stronger.

In even columns, we propose further robustness checks by restricting our sample to firms with headquarters in France (i.e. French multinationals). As can be seen, this does not affect our results either.

[Table 9 about here] 
Figure 1: Financial development and the technological content of exports

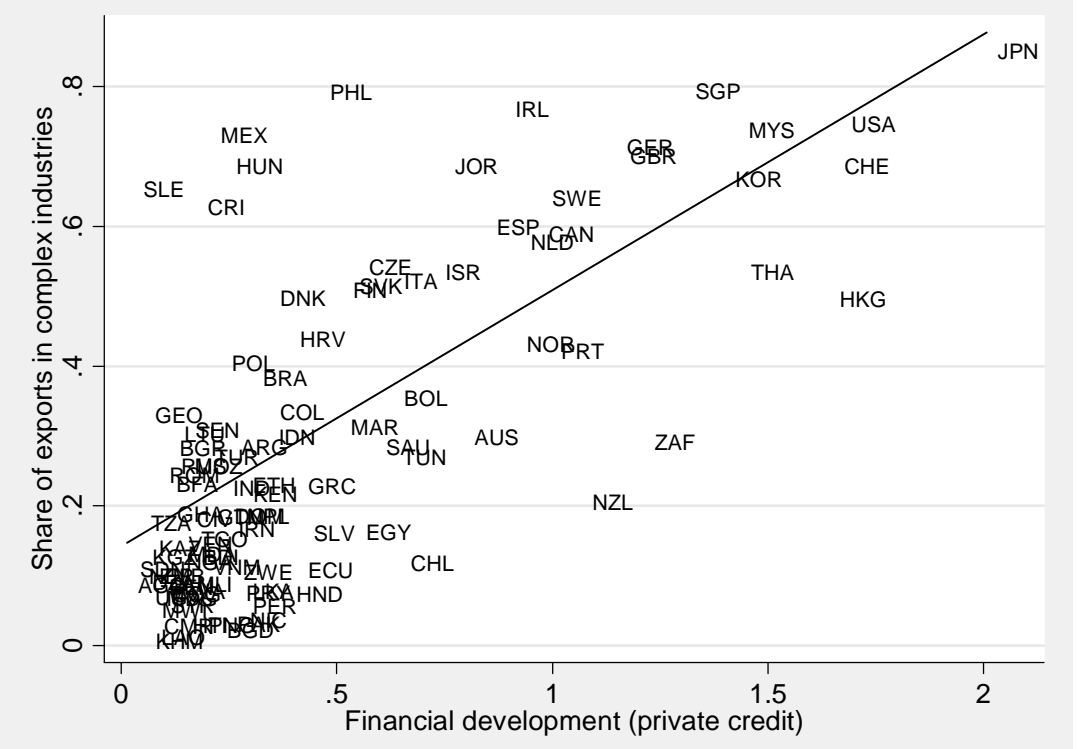


Figure 2: Sourcing mode and financial development
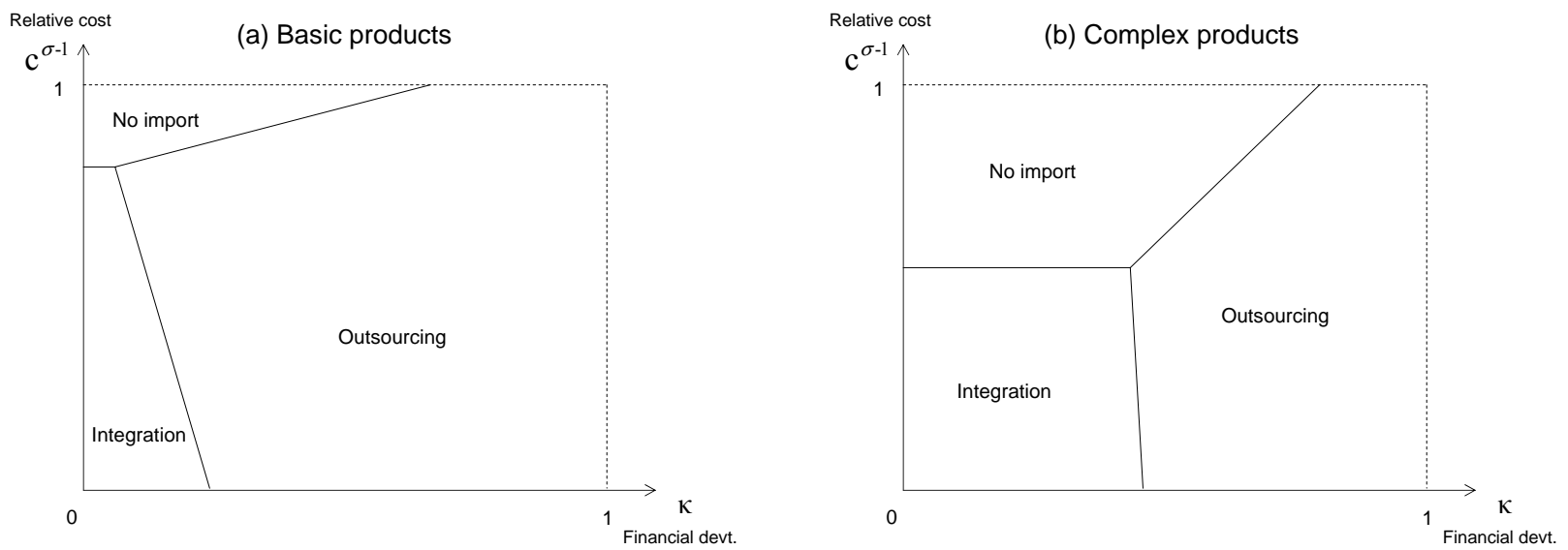


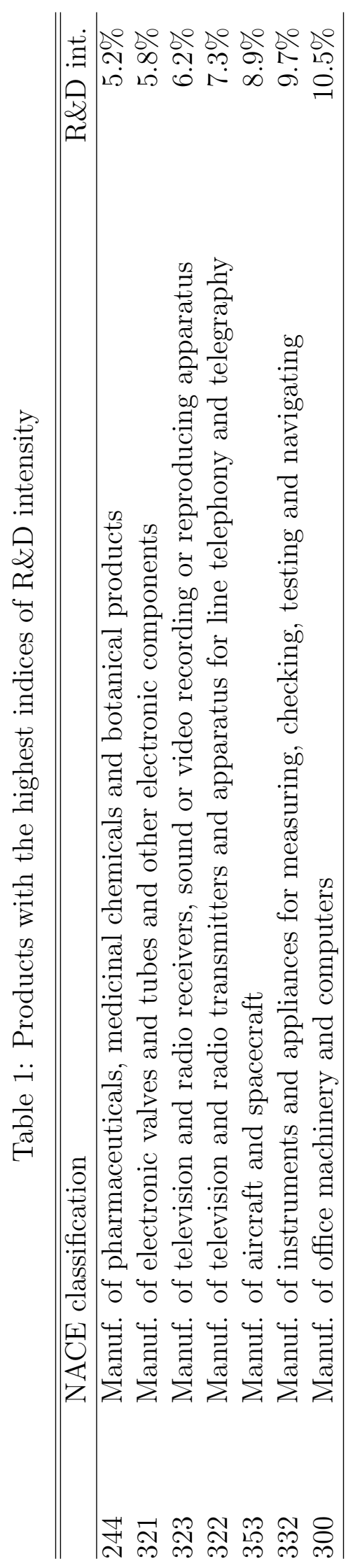




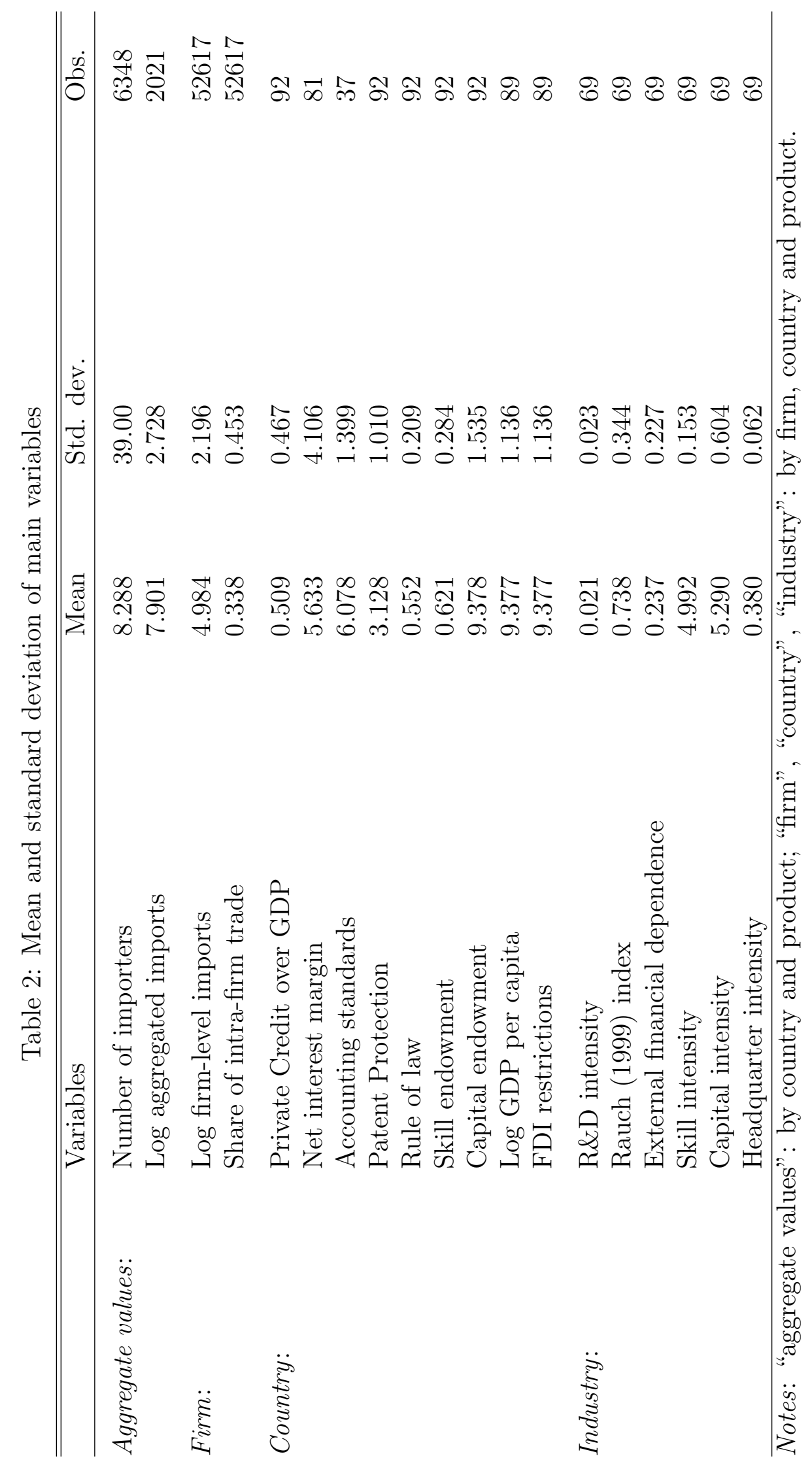


Table 3: Correlation between import variables and financial development (A) or product complexity (B)

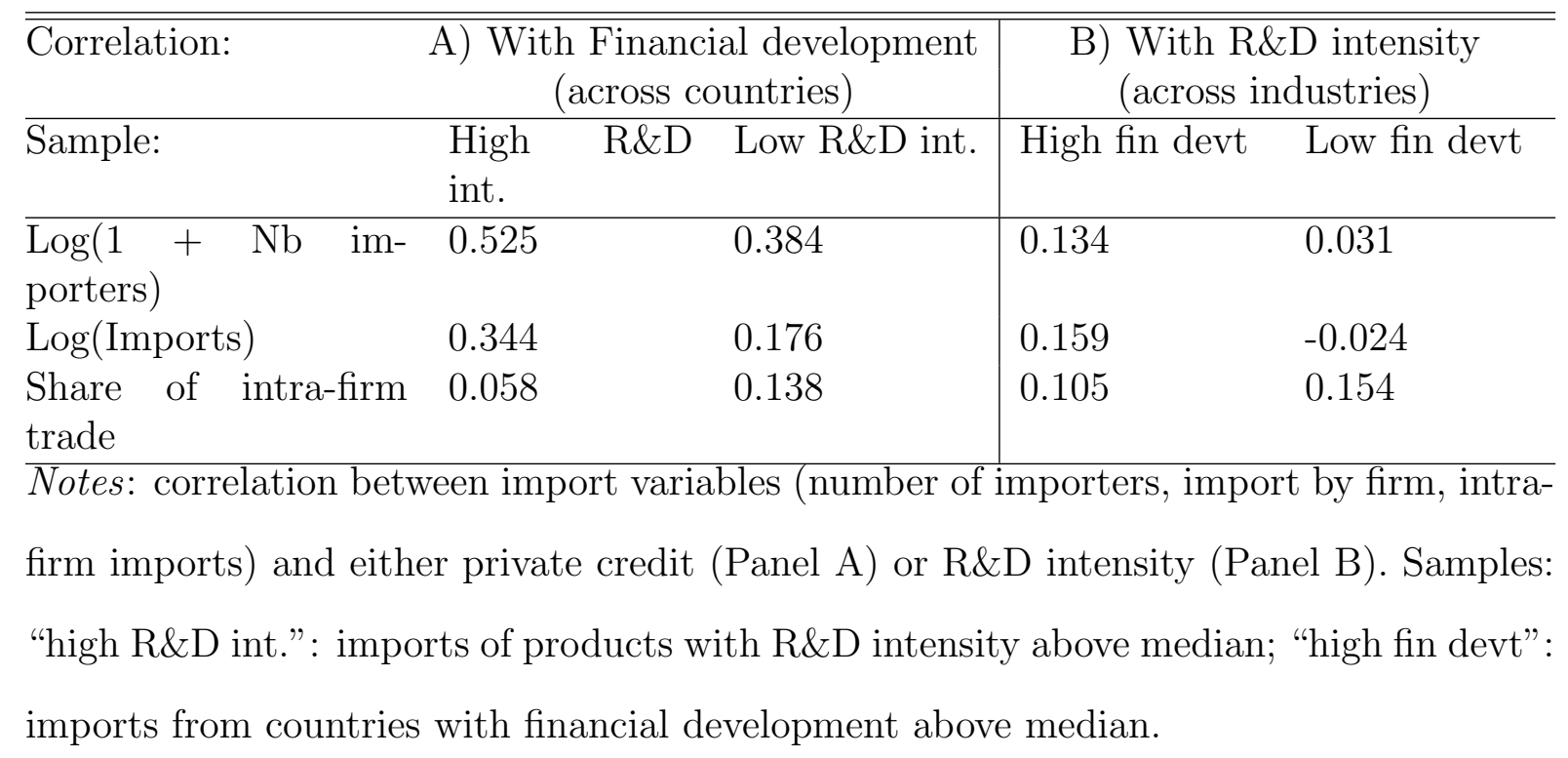


Table 4: Imports, product complexity and financial development

\begin{tabular}{|c|c|c|c|c|c|c|}
\hline \multirow[t]{2}{*}{ Dependent variable: } & \multicolumn{3}{|c|}{ Number of importers } & \multicolumn{3}{|c|}{ Value of imports } \\
\hline & $(1)$ & $(2)$ & $(3)$ & $(4)$ & $(5)$ & (6) \\
\hline (Fin devt)*(R\&D int.) & $\begin{array}{c}9.417 \\
{[3.263]^{* * *}}\end{array}$ & & $\begin{array}{c}9.066 \\
{[3.334]^{* * *}}\end{array}$ & $\begin{array}{c}19.888 \\
{[8.604]^{* *}}\end{array}$ & & $\begin{array}{c}22.826 \\
{[9.611]^{* *}}\end{array}$ \\
\hline$($ Fin devt $) *($ Rauch index $)$ & \multicolumn{3}{|c|}{$\begin{array}{c}0.682 \\
{[0.326]^{* *}}\end{array}$} & \multirow{2}{*}{\multicolumn{2}{|c|}{$\begin{array}{c}2.479 \\
{[0.840]^{* * *}}\end{array}$}} & \\
\hline$(\text { Fin devt })^{*}($ Ext fin dep $)$ & & & $\begin{array}{l}-0.309 \\
{[0.240]}\end{array}$ & & & $\begin{array}{c}-1.605 \\
{[0.661]^{* *}}\end{array}$ \\
\hline$(\text { Fin devt })^{*}($ Capital int, $)$ & & & $\begin{array}{c}-0.372 \\
{[0.166]^{* *}}\end{array}$ & & & $\begin{array}{c}-0.984 \\
{[0.423]^{* *}}\end{array}$ \\
\hline (Fin devt)*(HQ int.) & & & $\begin{array}{c}1.174 \\
{[0.684]^{*}}\end{array}$ & & & $\begin{array}{l}3.551 \\
{[2.919]}\end{array}$ \\
\hline (Patent prot)*(R\&D int.) & $\begin{array}{l}-0.228 \\
{[2.004]}\end{array}$ & $\begin{array}{c}1.677 \\
{[1.979]}\end{array}$ & $\begin{array}{l}-0.203 \\
{[1.985]}\end{array}$ & $\begin{array}{l}-1.075 \\
{[5.925]}\end{array}$ & $\begin{array}{l}4.176 \\
{[5.905]}\end{array}$ & $\begin{array}{l}-1.852 \\
{[6.063]}\end{array}$ \\
\hline \multirow{2}{*}{$\begin{array}{l}\text { (Rule of law })^{*}(\text { Rauch in- } \\
\text { dex })\end{array}$} & 2.121 & 1.074 & 1.766 & 4.038 & -0.149 & 4.111 \\
\hline & {$[0.609]^{* * *}$} & {$[0.914]$} & {$[0.621]^{* * *}$} & {$[1.571]^{* *}$} & [2.239] & {$[1.526]^{* * *}$} \\
\hline \multirow{2}{*}{$\begin{array}{l}(\mathrm{H} / \mathrm{L}) *(\text { Skill int. }) \\
(\mathrm{K} / \mathrm{L}) *(\text { Capital int. })\end{array}$} & $\begin{array}{c}4.261 \\
{[1.151]^{* * *}}\end{array}$ & $\begin{array}{c}4.561 \\
{[1.207]^{* * *}}\end{array}$ & $\begin{array}{c}4.681 \\
{[1.196]^{* * *}}\end{array}$ & $\begin{array}{c}6.939 \\
{[3.990]^{*}}\end{array}$ & $\begin{array}{c}7.705 \\
{[3.871]^{* *}}\end{array}$ & $\begin{array}{c}8.724 \\
{[3.964]^{* *}}\end{array}$ \\
\hline & $\begin{array}{c}0.221 \\
{[0.065]^{* * *}}\end{array}$ & $\begin{array}{c}0.207 \\
{[0.063]^{* * *}}\end{array}$ & $\begin{array}{c}0.296 \\
{[0.067]^{* * *}}\end{array}$ & $\begin{array}{c}0.258 \\
{[0.191]}\end{array}$ & $\begin{array}{c}0.241 \\
{[0.192]}\end{array}$ & $\begin{array}{c}0.472 \\
{[0.202]^{* *}}\end{array}$ \\
\hline$\alpha$ & 0.532 & 0.542 & 0.517 & 10.520 & 10.490 & 10.424 \\
\hline ummies & yes & yes & yes & yes & yes & yes \\
\hline Product dummies & yes & yes & yes & yes & yes & yes \\
\hline Obser & 6348 & 6348 & 6348 & 6348 & 6348 & 6348 \\
\hline Log pseudo-likelihood & -7447 & -7454 & -7432 & -23181 & -23175 & -23165 \\
\hline \multirow{2}{*}{\multicolumn{7}{|c|}{$\begin{array}{l}\text { Notes: dependent variables: number of multinationals with positive imports, by country } \\
\text { and product, and total value of imports. Negative binomial regressions. Main regressors: } \\
\text { interactions between country variables and product characteristics. "Fin devt": private }\end{array}$}} \\
\hline & & & & & & \\
\hline \multirow{2}{*}{\multicolumn{7}{|c|}{$\begin{array}{l}\text { credit over GDP; "Rauch index": equal to one for goods that are not traded on integrated } \\
\text { market or reference priced (Rauch, 1999); "Ext fin dep": dependence in external finance }\end{array}$}} \\
\hline & & & & & & \\
\hline \multicolumn{7}{|c|}{ (Rajan and Zingales, 1998); "Firm size": median firm size in the corresponding French } \\
\hline \multirow{2}{*}{\multicolumn{7}{|c|}{$\begin{array}{l}\text { industry; "HQ int.": headquarter intensity; "Patent prot": patent protection. } \alpha \text { : see } \\
\text { equation (10) in the text. Fixed effects by country and by product. Robust standard }\end{array}$}} \\
\hline & & & & & & \\
\hline errors into brackets, correc & ted for clus & ters 765 & & ficant at 1 & & ficant \\
\hline
\end{tabular}


Table 5: Imports, financial development and input complexity: other robustness checks

\begin{tabular}{|c|c|c|c|c|c|c|}
\hline \multirow[t]{2}{*}{ Dependent variable: } & \multicolumn{3}{|c|}{ Number of importers } & \multicolumn{3}{|c|}{ Value of imports } \\
\hline & $(1)$ & $(2)$ & $(3)$ & $(4)$ & $(5)$ & $(6)$ \\
\hline (Fin devt)*(R\&D int.) & $\begin{array}{c}10.935 \\
{[3.331]^{* * *}}\end{array}$ & & & $\begin{array}{c}24.692 \\
{[10.931]^{* *}}\end{array}$ & & \\
\hline (Int. $\quad$ margin $) *(R \& D$ & & -98.498 & & & -235.30 & \\
\hline & & {$[32.041]^{* * *}$} & & & {$[103.45]^{* *}$} & \\
\hline (Acc. stds) $*(\mathrm{R} \& \mathrm{D}$ int. $)$ & & & $\begin{array}{c}0.580 \\
{[0.161]^{* * *}}\end{array}$ & & & $\begin{array}{c}1.264 \\
{[0.336]^{* * *}}\end{array}$ \\
\hline 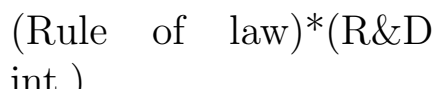 & -30.612 & & & -61.131 & & \\
\hline & {$[26.140]$} & & & {$[58.559]$} & & \\
\hline$(\mathrm{H} / \mathrm{L}) *(\mathrm{R} \& \mathrm{D}$ intensity $)$ & $\begin{array}{c}12.644 \\
{[16.640]}\end{array}$ & & & $\begin{array}{c}26.958 \\
{[41.027]}\end{array}$ & & \\
\hline$(\log \quad \mathrm{CGDP})^{*}(\mathrm{R} \& \mathrm{D}$ & 4.153 & & & 6.612 & & \\
\hline & {$[7.167]$} & & & {$[14.068]$} & & \\
\hline $\begin{array}{l}\text { (Patent prot }) *(\mathrm{R} \& D \\
\text { int.) }\end{array}$ & -1.519 & 1.263 & $-4.323^{*}$ & -4.312 & 6.338 & $-13.52^{* *}$ \\
\hline $\begin{array}{l}\text { (Rule of law)*(Rauch } \\
\text { ind) }\end{array}$ & $2.099^{* * *}$ & $1.947^{* * *}$ & $1.599^{*}$ & $3.955^{* *}$ & $3.448^{* *}$ & $3.247^{* *}$ \\
\hline (H/L)*(Skill int.) & $4.045^{* * *}$ & $4.127^{* * *}$ & $3.923^{* * *}$ & 5.864 & 5.409 & 5.052 \\
\hline$(\mathrm{K} / \mathrm{L})^{*}($ Capital int.) & $0.235^{* * *}$ & $0.235^{* * *}$ & $0.233^{* *}$ & 0.364 & 0.275 & 0.134 \\
\hline$\alpha$ & 0.525 & 0.537 & 0.457 & 10.434 & 9.737 & 5.852 \\
\hline Country dummies & yes & yes & yes & yes & yes & yes \\
\hline Product dummies & yes & yes & yes & yes & yes & yes \\
\hline Observations & 6141 & 5589 & 2553 & 6141 & 5589 & 2553 \\
\hline Log pseudo-likelihood & -7261 & -7379 & -5769 & -22556 & -22846 & -17306 \\
\hline
\end{tabular}

Notes: dependent variable: number of multinationals with positive imports, by country and product. Negative binomial regressions. Main regressors: interactions between country variables and product characteristics. "Fin devt": private credit; "Int. margin": net interest margin; "Accounting stds": accounting standards; "Log CGDP": log per capita GDP. $\alpha$ : see equation (10) in the text. Fixed effects by country and by product. Robust standard errors into brackets, corrected for clusters by country; * significant at $10 \% ;{ }^{* *}$ significant at $5 \%$; ${ }^{* * *}$ significant at $1 \%$. 
Table 6: Firm-level imports, financial development and input complexity

\begin{tabular}{|c|c|c|c|c|}
\hline \multirow[t]{2}{*}{ Dependent variable: } & \multicolumn{4}{|c|}{ Log firm-level imports } \\
\hline & (1) & $(2)$ & (3) & (4) \\
\hline (Fin devt)*(R\&D intensity) & $\begin{array}{c}6.377 \\
{[1.828]^{* * *}}\end{array}$ & $\begin{array}{c}7.522 \\
{[1.691]^{* * *}}\end{array}$ & $\begin{array}{c}8.190 \\
{[2.252]^{* * *}}\end{array}$ & $\begin{array}{c}9.141 \\
{[2.434]^{* * *}}\end{array}$ \\
\hline (Fin devt)*(Ext. fin. dep.) & & & $\begin{array}{c}-.096 \\
{[0.167]}\end{array}$ & \\
\hline (Fin devt)*(Capital intensity) & & & $\begin{array}{c}0.132 \\
{[0.066]^{* *}}\end{array}$ & \\
\hline (Fin devt)*(HQ intensity) & & & $\begin{array}{c}1.275 \\
{[0.920]}\end{array}$ & \\
\hline (Rule of law)*(R\&D intensity) & & & & $\begin{array}{c}8.538 \\
{[10.841]}\end{array}$ \\
\hline$(\mathrm{H} / \mathrm{L})^{*}(\mathrm{R} \& \mathrm{D}$ intensity $)$ & & & & $\begin{array}{l}-3.397 \\
{[7.747]}\end{array}$ \\
\hline$(\log \mathrm{CGDP}) *(\mathrm{R} \& \mathrm{D}$ intensity $)$ & & & & $\begin{array}{c}-6.965 \\
{[3.529]^{*}}\end{array}$ \\
\hline (Patent prot)*(R\&D intensity) & $-2.005^{*}$ & $-2.259^{* *}$ & $-2.251^{* *}$ & 2.154 \\
\hline (Rule of law)*(Rauch index) & -0.442 & -0.864 & -0.792 & $-0.940^{*}$ \\
\hline$(\mathrm{H} / \mathrm{L})^{*}($ Skil intensity $)$ & $2.442^{* * *}$ & $2.456^{* * *}$ & $2.424^{* * *}$ & $2.578^{* * *}$ \\
\hline$(\mathrm{K} / \mathrm{L}) *($ Capital intensity $)$ & 0.008 & 0.022 & 0.019 & 0.021 \\
\hline Firm dummies & no & yes & yes & yes \\
\hline Country and product dummies & yes & yes & yes & yes \\
\hline Observations & 52617 & 52617 & 52617 & 52164 \\
\hline R-squared & 0.07 & 0.25 & 0.25 & 0.25 \\
\hline
\end{tabular}

Notes: dependent variable: value of imports by firm, country and product. OLS regres-

sions. Main regressors: interactions between country variables and product characteristics. "Fin devt": private credit over GDP; "Ext fin dep": dependence in external finance (Rajan and Zingales, 1998); "HQ intensity": headquarter intensity; "Log CGDP": log per capita GDP; "Patent prot": patent protection. Fixed effects by country and by product; fixed effects by firm (columns 2 to 4). Robust standard errors into brackets, corrected for clusters by country; ${ }^{*}$ significant at $10 \% ;{ }^{* *}$ significant at $5 \% ;{ }^{* * *}$ significant at $1 \%$. 
Table 7: Intra-firm imports, financial development and input complexity

\begin{tabular}{|c|c|c|c|c|c|}
\hline \multirow[t]{2}{*}{ Dependent variable: } & \multicolumn{5}{|c|}{ Share of intra-firm imports } \\
\hline & $(1)$ & $(2)$ & $(3)$ & $(4)$ & $\overline{(5)}$ \\
\hline Estimation: & OLS & OLS & OLS & OLS & Logit \\
\hline \multirow[t]{2}{*}{$($ Fin devt $) *($ R\&D intensity $)$} & -0.702 & & -0.818 & -0.790 & -7.370 \\
\hline & {$[0.162]^{* * *}$} & & {$[0.196]^{* * *}$} & {$[0.162]^{* * *}$} & {$[2.446]^{* *}$} \\
\hline \multirow[t]{2}{*}{$($ Fin devt)*(Rauch index $)$} & & -0.037 & & & \\
\hline & & {$[0.013]^{* * *}$} & & & \\
\hline \multirow[t]{2}{*}{$(\text { Fin devt })^{*}($ Ext fin dep $)$} & & & 0.031 & & \\
\hline & & & {$[0.022]$} & & \\
\hline \multirow[t]{2}{*}{ (Fin devt)*(Capital intensity) } & & & 0.007 & & \\
\hline & & & {$[0.012]$} & & \\
\hline \multirow[t]{2}{*}{ (Fin devt)*(HQ intensity) } & & & 0.071 & & \\
\hline & & & {$[0.126]$} & & \\
\hline \multirow[t]{2}{*}{ (Rule of law)*(R\&D intensity) } & & & & 0.657 & \\
\hline & & & & {$[1.002]$} & \\
\hline \multirow[t]{2}{*}{ (Rule of law)*(Capital intensity) } & & & & -0.067 & \\
\hline & & & & {$[0.042]$} & \\
\hline \multirow{2}{*}{$\begin{array}{l}\text { (FDI restrictions }) *(\mathrm{R} \& D \text { inten- } \\
\text { sity) }\end{array}$} & & & & 0.005 & \\
\hline & & & & {$[0.012]$} & \\
\hline (Patent prot)*(R\&D intensity) & 0.211 & 0.109 & 0.224 & 0.075 & 0.884 \\
\hline (Rule of law)*(Rauch index) & $0.118^{* * *}$ & $0.176^{* * *}$ & $0.125^{* * *}$ & 0.046 & $1.514^{* * *}$ \\
\hline$(\mathrm{H} / \mathrm{L}) *($ Skill intensity $)$ & 0.039 & -0.017 & 0.016 & 0.064 & 0.492 \\
\hline$(\mathrm{K} / \mathrm{L}) *($ Capital intensity) & $0.010^{* *}$ & $0.011^{* *}$ & $0.009^{*}$ & $0.015^{* *}$ & 0.088 \\
\hline Firm dummies & yes & yes & yes & yes & yes \\
\hline Country and product dummies & yes & yes & yes & yes & yes \\
\hline Observations & 52617 & 52617 & 52617 & 52613 & 50159 \\
\hline R-squared or Log likelihood & 0.65 & 0.65 & 0.65 & 0.65 & -9672 \\
\hline
\end{tabular}

Notes: dependent variable: share of intra-firm imports, by firm, country and product.

OLS regressions except in column 5. Column 5: Logit regression, dropping mixed strategies (keeping observations where the dependent variable is either 0 or 1 ). Main regressors: interactions between country variables and product characteristics. "Fin devt": private credit over GDP; "Rauch index": equal to one for goods that are not traded on integrated market or reference priced (Rauch, 1999); "Ext fin dep": dependence in external finance (Rajan and Zingales, 1998); "HQ intensity": headquarter intensity; "Log CGDP": log per capita GDP; "Patent prot": patent protection. Fixed effects by firm, by country and by product. Robust standard errors into brackets, corrected for clusters by country; * significant at $10 \%$; ${ }^{* *}$ significant at $5 \% ;{ }^{* * *}$ Zsnificant at $1 \%$. 
Table 8: List of countries

\begin{tabular}{|c|c|c|c|}
\hline $\begin{array}{l}\text { Countries trading with } \\
\text { and other controls inclu }\end{array}$ & ultinational $\mathrm{f}$ & rance, with availabl & $\begin{array}{l}\text { data for private credit } \\
\text { of Table } 4) \text { : }\end{array}$ \\
\hline Algeria & Finland & Korea, South & Saudi Arabia \\
\hline Angola & Gabon & Madagascar & Senegal \\
\hline Argentina & Germany & Malaysia & Sierra Leone \\
\hline Australia & Ghana & Malta & Singapore \\
\hline Bangladesh & Greece & Mauritius & South Africa \\
\hline Benin & Guatemala & Mexico & Spain \\
\hline Bolivia & Guyana & Morocco & Sri Lanka \\
\hline Brazil & Haiti & Mozambique & Sweden \\
\hline Burkina Faso & Honduras & Netherlands & Switzerland \\
\hline Cameroon & Hong Kong & New Zealand & Syria \\
\hline Canada & Hungary & Nicaragua & Tanzania \\
\hline $\begin{array}{l}\text { Central African Re- } \\
\text { public }\end{array}$ & Iceland & Niger & Thailand \\
\hline Chad & India & Nigeria & Togo \\
\hline Chile & Indonesia & Norway & Trinidad and Tobago \\
\hline Colombia & Iran & Pakistan & Tunisia \\
\hline Congo & Ireland & Panama & Turkey \\
\hline Costa Rica & Israel & Papua New Guinea & Uganda \\
\hline Cyprus & Italy & Paraguay & United Kingdom \\
\hline Denmark & Ivory Coast & Peru & United States \\
\hline Ecuador & Jamaica & Philippines & Uruguay \\
\hline Egypt & Japan & Poland & Venezuela \\
\hline El Salvador & Jordan & Portugal & Zambia \\
\hline Fiji & Kenya & Romania & Zimbabwe \\
\hline
\end{tabular}




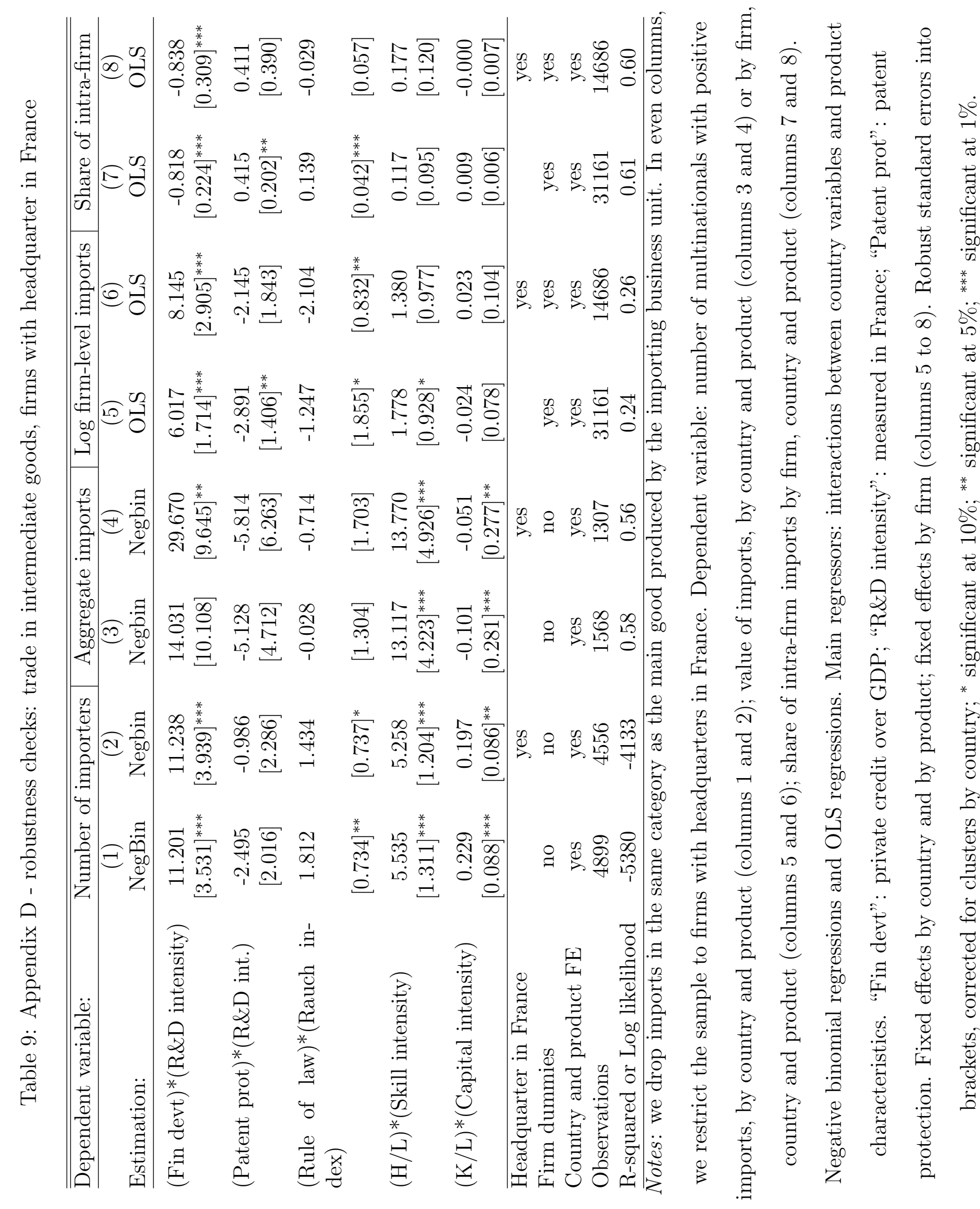

